Article

\title{
Emergency Capacity of Small Towns to Endure Sudden Environmental Pollution Accidents: Construction and Application of an Evaluation Model
}

\author{
Delu Wang ${ }^{1,2, *}$ and Yadong Wang ${ }^{2}$ \\ 1 International College of Applied Technology, Yibin University, Yibin 644000, China \\ 2 School of Economics and Management, China University of Mining and Technology, Xuzhou 221116, China; \\ ydwang@cumt.edu.cn \\ * Correspondence: dlwang@cumt.edu.cn
}

Citation: Wang, D.; Wang, Y

Emergency Capacity of Small Towns to Endure Sudden Environmental Pollution Accidents: Construction and Application of an Evaluation Model. Sustainability 2021, 13, 5511. https://doi.org/10.3390/su13105511

Academic Editor: Changhyun Roh

Received: 15 April 2021

Accepted: 13 May 2021

Published: 14 May 2021

Publisher's Note: MDPI stays neutral with regard to jurisdictional claims in published maps and institutional affiliations.

Copyright: (c) 2021 by the authors. Licensee MDPI, Basel, Switzerland. This article is an open access article distributed under the terms and conditions of the Creative Commons Attribution (CC BY) license (https:// creativecommons.org/licenses/by/ $4.0 /)$.

\begin{abstract}
Sudden environmental pollution accidents (SEPAs) in small towns are characterized by high uncertainty, complex evolution, and fast spread speed, and they cause serious harm to a wide geographic range. Thus, SEPAs greatly challenge the emergency management systems of enterprises and governments. Therefore, improving the emergency capacity of small towns (ECST) to withstand SEPAs deserves more attention. In this study, the evolution mechanism of SEPAs is systematically analyzed, revealing the interactions among various situational elements in the SEPA occurrence process. Then, an evaluation index system of the ECST response to SEPAs is constructed based on four dimensions: monitoring and early warning capacity, preparedness and mitigation capacity, response, and recovery capacity. The system includes 68 indicators and covers the key stages of the SEPA life cycle. Finally, an evaluation model of the ECST to SEPAs is proposed based on the analytic network process method, and the small town of Jiangyin City is selected as a case study for empirical evaluation. The proposed evaluation model considers the interactions and interdependent feedback between indexes, effectively improving the accuracy and scientific nature of the evaluation results. Thus, this model provides a solid decision-making reference for governments and a quantitative theoretical basis for the formulation of measures targeted at SEPAs.
\end{abstract}

Keywords: emergency capacity; sudden environmental pollution accident; small towns; evaluation model; analytic network process method

\section{Introduction}

China's urbanization level has steadily improved in recent years. At the end of 2020, the average urbanization rate in China reached $61.5 \%$, and it is expected to increase to $68 \%$ by 2030 and exceed $80 \%$ by 2050 [1]. According to the China City Development Report of 2019 and 2020, the urbanization rate in the Yangtze River Delta region, which has relatively prosperous economic development, reached $70 \%$ in 2020 [2]. In particular, the urbanization rate of Suzhou, Wuxi, Changzhou, and other cities located in the southern part of Jiangsu Province all exceeded 79\% in 2020, far exceeding the national average [2]. Jiangsu is one of the most economically active provinces in China, with its comprehensive economic competitiveness ranking among the top in China. According to the Jiangsu Provincial Bureau of Statistics (Available online: http:/ / stats.jiangsu.gov.cn/art/2021/3 /10/art_4031_9698925.html (accessed on 10 March 2021)), Jiangsu's GDP in 2020 reached CNY 10.27 trillion, with per capita GDP reaching CNY 125,000, ranking first among all provinces (autonomous regions) in China. Moreover, Jiangsu Province has 13 prefecturelevel administrative regions under its jurisdiction, all of which are ranked among the top 100 , making it the only province in which all the prefecture-level administrative regions are ranked among the top 100. Its comprehensive competitiveness and regional development and people's livelihood index (DLI) rank among the top provinces in China, and it has 
become one of the provinces with the highest comprehensive development level in China. The rapid increase of urbanization has stimulated China's economic development, but it has also brought some challenges [3]. Extensive and rapid expansion has led to a mismatch between the speed and quality of urban development, which deviates from China's initiatives toward high-quality development and causes a series of social and environmental problems. Specifically, a large number of people and industrial parks exist in cities and small towns, which leads to the disorderly expansion of land, destruction of spatial distribution forms, insufficient sewage and garbage treatment capacities, polluted natural resources including air, water, and soil, and great challenges to the resource carrying capacity $[4,5]$. For example, as a big manufacturing province, Jiangsu Province has a huge amount of industrial sewage discharge, which brings great pressure to the water source protection of the Yangtze River Basin. In summary, the rapid expansion of urban areas causes the urban environmental system to become more complex. As the types and number of environmental risk sources constantly increase, a sudden environmental pollution accident (SEPA) can easily occur. A SEPA is characterized by high uncertainty, complex evolution, and a fast spread speed, and it causes serious harm to a wide geographic range. Compared with large cities, small towns have limited facilities related to emergency management. In particular, small towns have large and scattered populations, limited public management capacities, weak infrastructure, and late starts in their emergency management systems [6]. Once a SEPA occurs, it leads to huge environmental and economic losses, and also causes difficulties and puts pressure on the emergency management systems of enterprises and governments [7,8]. According to the Ministry of Emergency Management of China (Available online: https: / /www.mem.gov.cn/xw/bndt/202012/t2 0201208_374872.shtml (accessed on 8 December 2020)), from January to November of 2020, 127 SEPAs occurred in China's chemical industry alone, resulting in a total of 157 deaths, 7718 injuries, and direct and indirect economic losses reaching hundreds of billions of yuan. Therefore, developing an evaluation index system and model for the emergency capacity of small towns (ECST) to SEPAs has become a basic method for strengthening China's emergency management and prevention techniques. Such a method is not only useful for measuring the current emergency capability and formulating practical and targeted emergency management measures, but it can also guide small towns to make more effective and science-based decisions when responding to SEPAs.

Given that sudden disasters are typically characterized by abruptness, uncertainty, and severe destructiveness, many scholars have conducted extensive studies on the related evolutionary mechanisms $[9,10]$, early warning methods [11,12], emergency resource scheduling, and emergency decision-making $[8,13]$. Considering that emergency ability plays an important role in disaster prevention and mitigation, the issue of emergency ability has recently received more attention in academia. The existing research has mainly focused on conceptual analysis [14], influential factors [15,16], evaluation index systems [7,17], and evaluation models $[18,19]$, which provide a solid theoretical basis and sound practical guidance for the construction and improvement of emergency management systems. However, three gaps remain in the literature. First, emergency responses and management in big cities have become a hot topic in social research, as many SEPAs have occurred in urbanized areas; however, SEPAs in small towns, which account for the largest proportion of all SEPAs in China, have not received due attention. Compared with supercities and large cities $[10,20]$, small towns have limited economic and environmental bearing capacity, and weak emergency response infrastructure and capacity, which are quite complex problems in emergency management work [21]. Therefore, the problem of how to improve the ECST response to SEPAs urgently needs to be resolved. Second, the existing research pays more attention to natural disasters, such as floods, earthquakes, and meteorological disasters $[12,15,16]$, than to sudden disasters, such as transportation accidents and safetyrelated accidents occurring in businesses and public life [19,22]. However, few studies have investigated sudden environmental pollution and ecological destruction accidents. Because natural disasters generally have strict rules which are followed as a response, 
governments and relevant departments have rich experience working in emergency management and prevention [20]. However, SEPAs always have complex mechanisms and uncertain characteristics. Small towns have very limited economic and environmental resources, and thus it is very easy for them to experience negative chain reactions of SEPAs. Therefore, it is necessary to discuss SEPAs that have occurred in small towns. Third, the current evaluation models, such as the analytic hierarchy process (AHP) $[7,23,24]$, fuzzy comprehensive evaluation (FCE)-AHP [25], and models based on machine learning such as AHP-Back Propagation (BP) [26], consider the linear relationship between the selected indexes but ignore the complex dynamic interactions between the elements in the SEPA evolution system. Thus, the current models weaken the validity and accuracy of index weighting and evaluation results.

In this context, this study reveals the SEPA evolution mechanism, constructs an evaluation index system based on the life cycle perspective of emergencies, proposes an evaluation model of the ECST to SEPAs based on the analytic network process (AHP) method, and finally conducts an empirical evaluation of Jiangyin City, China. This study not only enriches the evaluation index system and scope of emergency capability research but also provides important guidance for improving regional emergency management capability and optimizing national emergency strategies for SEPAs. This guidance consists of three contributions. First, it is of strategic significance to evaluate the emergency capacity of small towns with relatively limited emergency resources in order to achieve high-quality and balanced urban development. Moreover, this evaluation compensates for the gap in integrated research on the ECST and SEPAs in the field of emergency capacity evaluation research. Second, an evaluation index system including four dimensions-specifically monitoring and early warning, preparedness and mitigation, response, and recovery capabilities-is constructed. The index system comprehensively covers the key stages of the life cycle of the ECST to SEPAs, which enriches the research basis of the evaluation index system of emergency management capability. Finally, an effective evaluation model based on the ANP method is proposed. Compared with previous studies, this model considers the mutual influence of and interaction between internal indexes and indexes of adjacent layers when conducting index weighting, contributing to the efficient evaluation results of the ECST to SEPAs.

\section{Materials and Methods}

\subsection{Literature Review}

\subsubsection{Notion of ECST}

Emergency capacity is the comprehensive capacity to cope with emergencies such as natural disasters, sudden public health accidents, safety accidents, and military conflicts $[27,28]$. With the frequent occurrence of emergencies, emergency capacity enhancement has become an important part of the management capacity of governments and other public institutions $[20,29]$. Table 1 summarizes the contents of emergency management systems in different countries in terms of emergency management organizations, emergency response mechanisms, emergency legal systems, and emergency response plans. Compared with Europe, America, and Japan, China's emergency management system remains weak when considering the expertise of emergency management organizations, the dynamism of the emergency legal system, and the soundness of the emergency response plan. Especially, emergency management abilities and resources are relatively limited in small towns of China. 
Table 1. Comparison of emergency management contents in different countries.

\begin{tabular}{|c|c|c|c|c|}
\hline Country & Emergency Management Organization & Emergency Response Mechanism & Emergency Legal System & Emergency Response Plan \\
\hline America & $\begin{array}{l}\text { It is mainly composed of three levels of } \\
\text { federal, state, and local (county, city, and } \\
\text { community). At the federal government } \\
\text { level, there are mainly the Department of } \\
\text { Homeland Security, Emergency } \\
\text { Management Agency and its affiliated } \\
\text { agencies (10 regional offices). At the state } \\
\text { and local government levels, there are } \\
\text { emergency management leadership } \\
\text { agencies and working agencies. }\end{array}$ & $\begin{array}{l}\text { Based on the National Incident } \\
\text { Management System (NIMS), } \\
\text { strengthening the emergency response } \\
\text { mechanism construction, establishing a } \\
\text { coordinated and efficient emergency } \\
\text { response mechanism with the } \\
\text { characteristics of unified management, } \\
\text { territorial orientation, hierarchical } \\
\text { response, and standard operation. }\end{array}$ & $\begin{array}{l}\text { An emergency legal system } \\
\text { dominated by federal laws and } \\
\text { regulations, executive orders, } \\
\text { procedures, and standards. From } \\
\text { the legal force, the Constitution is at } \\
\text { the top of the list, followed by the } \\
\text { National Emergency Law. } \\
\text { Additionally, there are emergency } \\
\text { plans and designs that directly } \\
\text { regulate emergency disposal. }\end{array}$ & $\begin{array}{l}\text { The emergency response plans of } \\
\text { governments at all levels and relevant } \\
\text { units are formulated by the guidance of } \\
\text { the Emergency Preparedness Guide: } \\
\text { Revised Guide for Local Government } \\
\text { Emergency Plans (CPG101). }\end{array}$ \\
\hline Japan & $\begin{array}{l}\text { Japan's emergency management } \\
\text { organization is divided into three levels: } \\
\text { the central government, prefectures, and } \\
\text { municipalities. Governments at all levels } \\
\text { regularly hold disaster response meetings, } \\
\text { such as the central disaster prevention } \\
\text { meeting, the prefectures disaster prevention } \\
\text { meeting, and the municipalities disaster } \\
\text { prevention meeting. }\end{array}$ & $\begin{array}{l}\text { Japan's emergency response mechanism } \\
\text { is divided into pre-event, in-event, and } \\
\text { post-event stages, namely prevention, } \\
\text { response, and recovery mechanisms, } \\
\text { and with prominent priorities and clear } \\
\text { responsibilities in each stage. }\end{array}$ & $\begin{array}{l}\text { Based on the Basic Law of Disaster } \\
\text { Countermeasures and a series of } \\
\text { related specific regulations, the legal } \\
\text { system of emergency management } \\
\text { is formulated, which provides an } \\
\text { important institutional guarantee } \\
\text { for the effective implementation of } \\
\text { disaster prevention and mitigation } \\
\text { work. }\end{array}$ & $\begin{array}{c}\text { Japan's emergency response plan } \\
\text { consists of a disaster prevention plan } \\
\text { structure, a special disaster prevention } \\
\text { plan, and a regional disaster prevention } \\
\text { plan from top to bottom. }\end{array}$ \\
\hline $\begin{array}{l}\text { The European Union } \\
\text { (represented by } \\
\text { Germany) }\end{array}$ & $\begin{array}{l}\text { The emergency management organization } \\
\text { of Germany is decentralized management } \\
\text { by the federal, state, and local governments, } \\
\text { which is dominated by the state } \\
\text { government and territorial management. }\end{array}$ & $\begin{array}{l}\text { The emergency response mechanism } \\
\text { emphasized that the emergency } \\
\text { management should move forward and } \\
\text { promote the establishment of a } \\
\text { mechanism featuring social } \\
\text { participation, flexible services, and close } \\
\text { cooperation with the government, so as } \\
\text { to realize the transformation from } \\
\text { passive response to active protection. }\end{array}$ & $\begin{array}{l}\text { Germany's emergency legal system } \\
\text { is based on the Constitution (Basic } \\
\text { Law of Germany), with a series of } \\
\text { separate laws such as the Civil } \\
\text { Protection Law and the Disaster } \\
\text { Protection Law as the core, and the } \\
\text { federal and state work as the } \\
\text { coordination. }\end{array}$ & $\begin{array}{l}\text { Some emergency response plans } \\
\text { covering a wide range of areas from the } \\
\text { federal government to the state } \\
\text { government and various enterprises } \\
\text { have been established. The government } \\
\text { strictly supervises, tracks, and } \\
\text { investigates emergency plans in each } \\
\text { level, and guides the revision and } \\
\text { improvement of different emergency } \\
\text { plans according to the actual situation. }\end{array}$ \\
\hline China & $\begin{array}{l}\text { The emergency management organizations } \\
\text { are characterized with unified leadership, } \\
\text { comprehensive coordination, classified } \\
\text { management, graded responsibility, and } \\
\text { territorial management-oriented. }\end{array}$ & $\begin{array}{l}\text { The emergency management } \\
\text { mechanism is operated by the main } \\
\text { workflow of "risk } \\
\text { assessment-monitoring and early } \\
\text { warning-emergency response and } \\
\text { recovery. }\end{array}$ & $\begin{array}{l}\text { The emergency legal system is } \\
\text { based on the Constitution, with the } \\
\text { Emergency Response Law as the } \\
\text { core, and the relevant individual } \\
\text { laws and regulations as a } \\
\text { supporting set. }\end{array}$ & $\begin{array}{l}\text { The emergency response plan system } \\
\text { consists of six levels: national response } \\
\text { plan, specific response plan, } \\
\text { departmental response plan, local } \\
\text { response plan, enterprise and public } \\
\text { institution response plan, and big event } \\
\text { response plan. }\end{array}$ \\
\hline
\end{tabular}


The ECST is reflected in the allocation of urban emergency resources and the executive power of urban institutions during emergencies [30]. It largely depends on natural conditions and the ability to prevent and respond to unexpected accidents. The ECST is a dynamic process under the comprehensive influence of various external environments, such as meteorological, legal, social, and economic environments [8,9]. Based on the characteristics of small towns in China, this paper defines the ECST as the behavioral ability of local governments and the cooperating departments of small towns to deal with the entire life cycle of natural disasters and sudden accidents in terms of monitoring and early warning, preparedness, mitigation, response, and recovery. Figure 1 systematically analyzes the connotations of the ECST from the target layer, measure layer, and index layer.

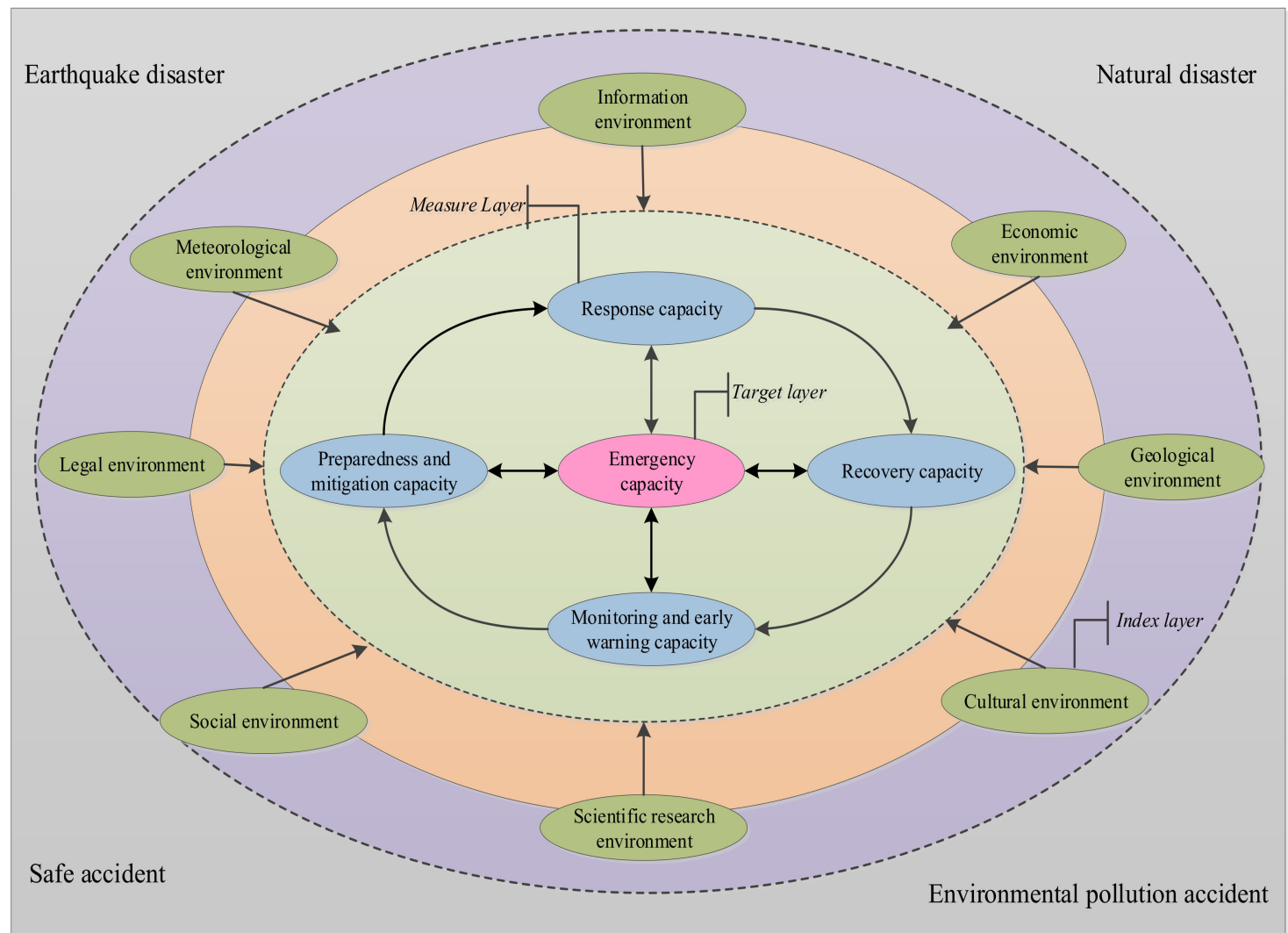

Figure 1. Conceptual representation of emergency capacity.

\subsubsection{Notion of SEPA}

Sudden accidents are characterized by insufficient precursors, obvious complexity, potential secondary hazards, and serious destructiveness, and it is difficult to effectively deal with these accidents using conventional emergency management measures [31,32]. The emergency management of sudden accidents is different from other types of event management because unconventional sudden accidents are characterized by strong abruptness, poor foresight, wide influence, great damage, and poor prognosis. As a result, general emergency management measures are inadequate for dealing with such complex disasters, which brings great challenges to the decision-making processes of emergency managers [8]. A perfect emergency management system for a sudden accident is based on the entire management process (i.e., before, during, and after the emergency; covering multiple stages and processes of early warning, control, and disposal), using various methods to achieve disaster prevention and mitigation [19]. A SEPA refers to an emergency that may cause great loss to lives and property due to economic and social activities and behaviors that violate environmental protection laws and regulations, and to emergencies caused by unexpected factors or unpreventable natural disasters [33]. Since there are no regular laws 
or fixed determinants for the occurrence of a SEPA, the time, place, and pollutants of the accident are very uncertain. SEPAs occur suddenly and become fierce, causing environmental pollution in a short period of time. These events are difficult to resolve and eliminate, and thus seriously impact public safety and social stability $[3,8]$. Therefore, in small towns with relatively weak emergency capacity, optimizing the emergency management systems for SEPAs and determining how to avoid or minimize the negative impacts of such accidents have become urgent problems for emergency management organizations and the field of emergency research.

\subsubsection{Evaluation of Emergency Capacity}

The purpose of emergency management capacity assessment is to determine the existing deficiencies that require optimization and thus improve the emergency management capacity. In the face of natural disasters, production safety accidents, and environmental pollution accidents, the evaluation of emergency capability is comprehensive and complex, and it includes preparedness for emergencies, the rationality of the emergency construction investment, the ability of the public to obtain disaster information, the capacity of government agencies to provide relief, and so on $[18,24,34]$. As an important issue in emergency management, emergency capacity assessment has been of great importance to governments and emergency departments in many countries, especially in areas with frequent natural and social disasters. Currently, the Chinese government has no official documents on the evaluation criteria for emergency management capability [35]. Meanwhile, emergency management as a complex scientific problem involving multiple fields has been extensively addressed in academia when discussing the evaluation of emergency capacity [36]. Some studies have discussed the evaluation index system, including qualitative methods (e.g., theoretical research, case analysis [34], and Delphi expert consultation [28]) and quantitative methods (e.g., structural equation model, interpretive structure model, decision testing, and laboratory evaluation [37-39]). In the existing studies on emergency capability evaluation methods, many scholars have introduced interdisciplinary knowledge, such as AHP [7,23], FCE and fuzzy clustering [40], fuzzy AHP [28], the extension rhombus thinking method [41], the entropy weight method [39], and some integration methods [18,37]. Each of these methods has advantages and disadvantages and provides a valuable instrument for emergency capacity evaluation. However, because the involved indexes are complex and scattered, the current evaluation research on emergency capacity usually ignores the relevance and interactions between the internal elements in the SEPA evolution system, which may reduce the accuracy and effectiveness of the evaluation results.

\subsection{Evaluation Index System and Model}

\subsubsection{Framework}

The evaluation result of the ECST to SEPAs is based on the soundness of the evaluation index system and evaluation model. Therefore, this paper proposes an evaluation framework of the ECST to SEPAs (see Figure 2), covering the whole process of "mechanism analysis—index system construction-model establishment—empirical evaluation." The four phases are as follows:

Phase 1: The situational elements and evolutionary mechanism of a SEPA are analyzed theoretically, and the interaction and dependent feedback relationships among various situational elements are revealed, thus providing a solid theoretical basis for the construction of the evaluation index system.

Phase 2: Construction of a multidimensional evaluation index system. Based on the analysis of the evolution mechanism of the SEPA and from the perspective of the entire life cycle of the accident, the corresponding evaluation indexes were selected to construct the evaluation index system of the ECST to the SEPA using multiple dimensions.

Phase 3: Establishment of the evaluation model based on the ANP method. Given the interactions between the evaluation indexes, the ANP method was selected for index weighting and scoring. 
Phase 4: Implementation of empirical evaluation. To verify the effectiveness of the index system and evaluation model proposed in this study, a representative case was selected for empirical evaluation and discussion.

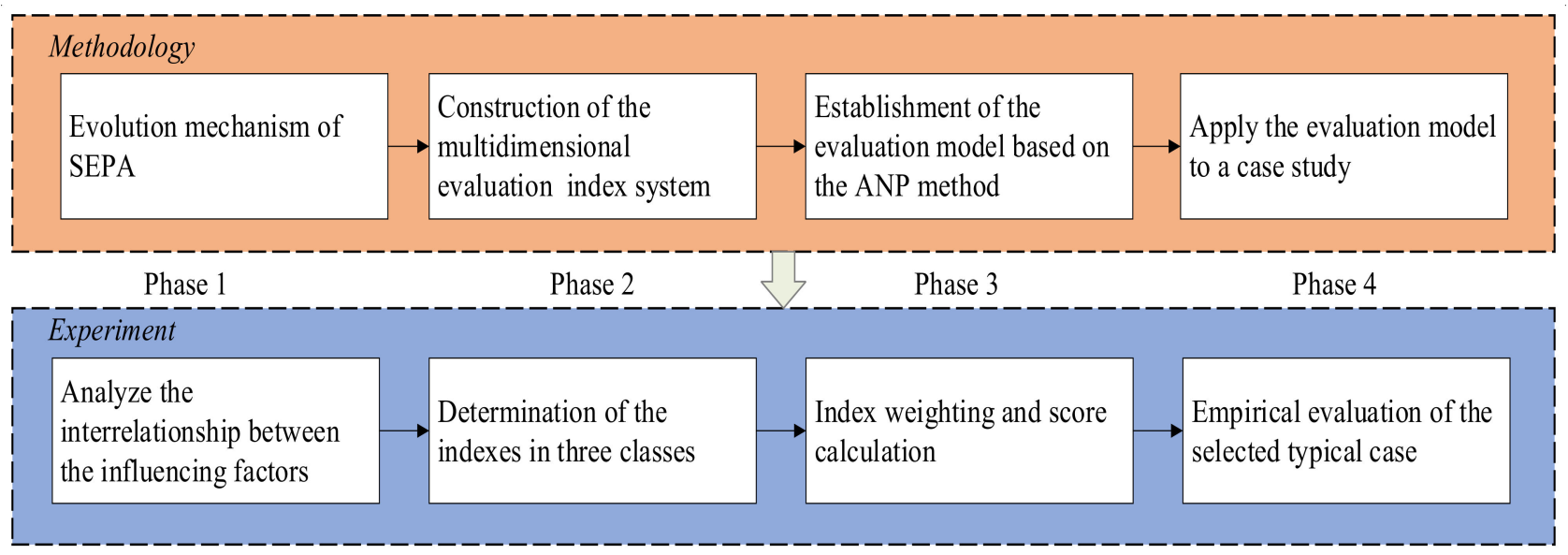

Figure 2. The proposed evaluation framework of the ECST to SEPAs.

\subsubsection{Construction of the Evaluation Index System}

Evolution Mechanism of a SEPA

The mechanism of a sudden accident refers to the principles and laws that are followed during emergence, development, derivation, and diffusion of an emergency; this is the basis of emergency management. Through mechanism analysis, emergency management organizations can clarify the internal dynamic mechanism of a SEPA to determine and analyze the relevant influencing factors $[14,15]$. In this paper, we define the information that reflects the main characteristics and influencing factors of a SEPA as "scene elements." According to the theory of disaster science, scene elements are composed of four main parts: the disaster-inducing factor, the disaster-generating environment, the disaster-bearing body, and the SEPA [8], as shown in Figure 3. The disaster-inducing factor is the sufficient condition for the occurrence of the disaster, the disaster-bearing body is the necessary condition for the amplification or mitigation of the disaster, and the disaster-generating environment is the background condition affecting the former two. Intuitively, the evolution of a SEPA is performed under certain complex conditions. Specifically,

1. Disaster-inducing factors: Disaster-inducing factors can be safety accidents, production accidents, illegal discharge, the contaminated body, or other inducing factors that cause a SEPA. For emergency management, the systematic consideration of the relationship between disaster-inducing factors and other dynamic situational factors is a key issue for the overall response and disposal of a SEPA.

2. Disaster-generating environment: A disaster-generating environment refers to the natural and social environment in the affected area where an emergency occurs. Specifically, it includes factors such as weather, hydrology, meteorology, and geology that act on the contaminated body to reduce or enhance the degree of environmental pollution. In general, a disaster-generating environment directly affects the consequences of a SEPA.

3. Disaster-bearing body: The disaster-bearing body is the combination of the disaster, the external environment, and the applied emergency management. In addition to basic attributes, it also contains spatial distribution information and disaster resistance capacity. From the perspective of emergency management, the necessary conditions for aggravating or mitigating disasters include not only the disaster-bearing body but also the government's emergency management department, whose timely and effective emergency management is an important factor for reducing the harmfulness of disasters. 
4. SEPA: Emergency management is the process of early warning, control, and disposal of emergencies. The corresponding subjects are the personnel, organizations, and institutions dealing with the emergencies, and the objects are all the possible types of emergencies. A perfect emergency management system is based on the management process of the entire life cycle of the event, including multiple stages of early warning, control, disposal, and so on.

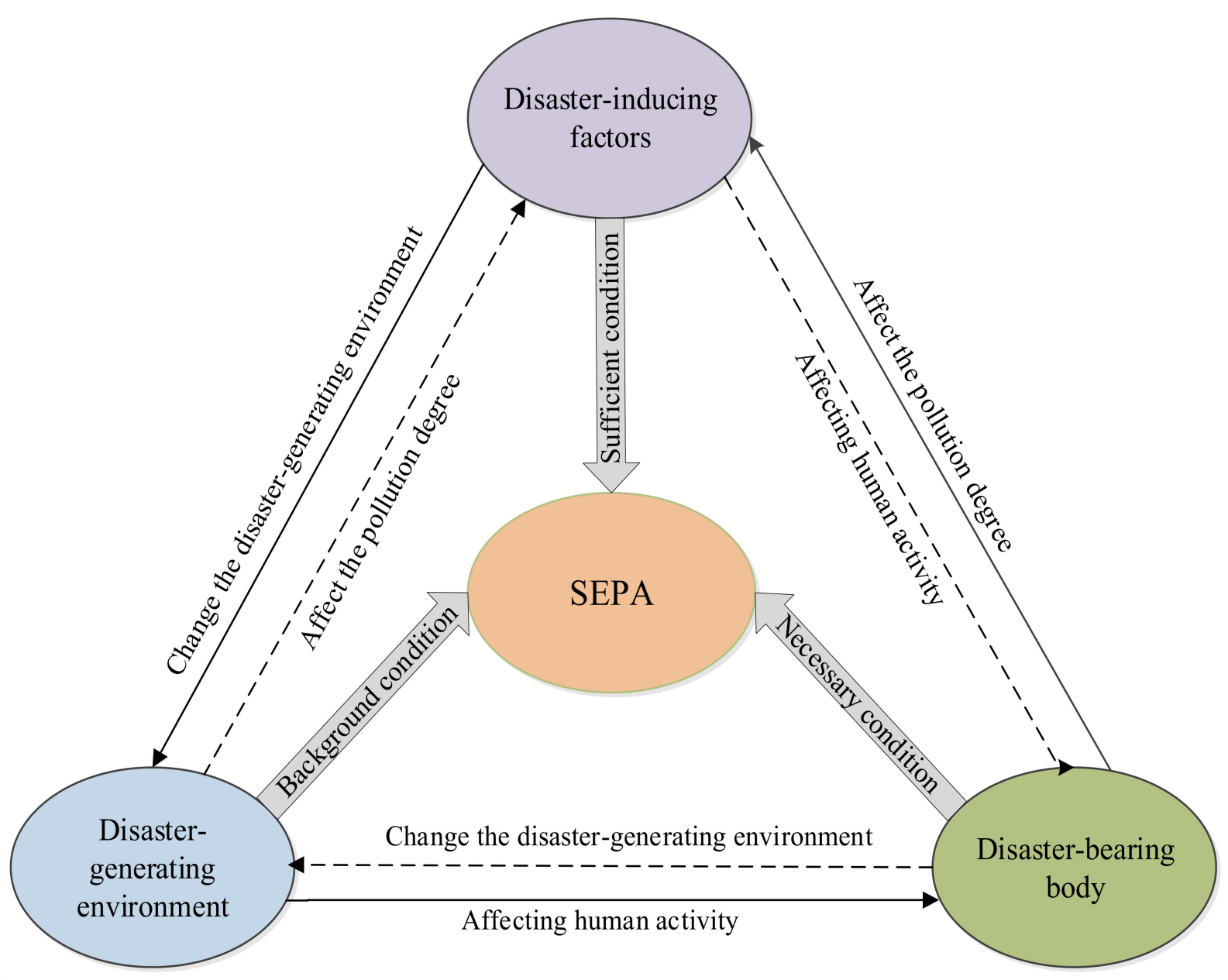

Figure 3. The evolution mechanism of a SEPA.

\section{Determination of the Indexes}

By referring to the theoretical research and practical experience of the international evaluation index system for urban emergency capacity, an evaluation index system that can represent the ECST to SEPAs has been systematically established from the perspective of the entire emergency life cycle. The index system is composed of four layers: the target layer, the first-class index layer, the second-class index layer, and the third-class index layer. According to the life cycle stages of emergency management, the first-class indexes are divided into four dimensions: monitoring and early warning capacity, preparedness and mitigation capacity, response capacity, and recovery capacity. Specifically, monitoring and early warning capacity refers to the ability to monitor, collect, screen, sort, analyze, and evaluate the information about a possible event according to its main inducer and symptoms before a SEPA occurs, to determine the type and scope of the possible event and to provide a timely warning. Preparedness and mitigation capacity refers to the efforts and preparations made by the government and relevant departments to actively respond to the occurrence of an accident before it occurs, including the ability to provide publicity and education, emergency plans, and resource guarantees. Response capacity refers to the 
ability of the government and relevant departments to identify the type and level of an event after its occurrence. It also includes the ability to make timely decisions according to existing emergency response plans by sorting and analyzing the impact of the event and forecasting the trends of future development. Resilience capacity refers to the ability of the government and relevant departments to bring the affected areas and people back to normal production, life, work, and social order through recovery and reconstruction after the disposal of the accident. To obtain more specific evaluation indicators, the above four types of capacity are divided more specifically according to the standards and work requirements of China's urban emergency plan management system. Each first-class index is divided into three second-class indexes: organizational and coordination capacity, resource guarantee capacity, and environmental support capacity.

Based on the comprehensive consideration of the evaluation index system construction principles, the results of expert interviews, the investigation of the status quo of small-town emergency management, and the exploration of the emergency capacity evaluation index system in the field of emergency research, we finally established a SEPA evaluation index system including 68 third-class indexes, which are described in Table 2. Specifically, the dimension of monitoring and early warning capacity includes 14 indexes, the dimension of preparedness and mitigation capacity includes 15 indexes, the dimension of response capacity includes 23 indexes, and the dimension of resilience capacity includes 16 indexes. Figure 4 shows the hierarchical structure of the constructed index system.

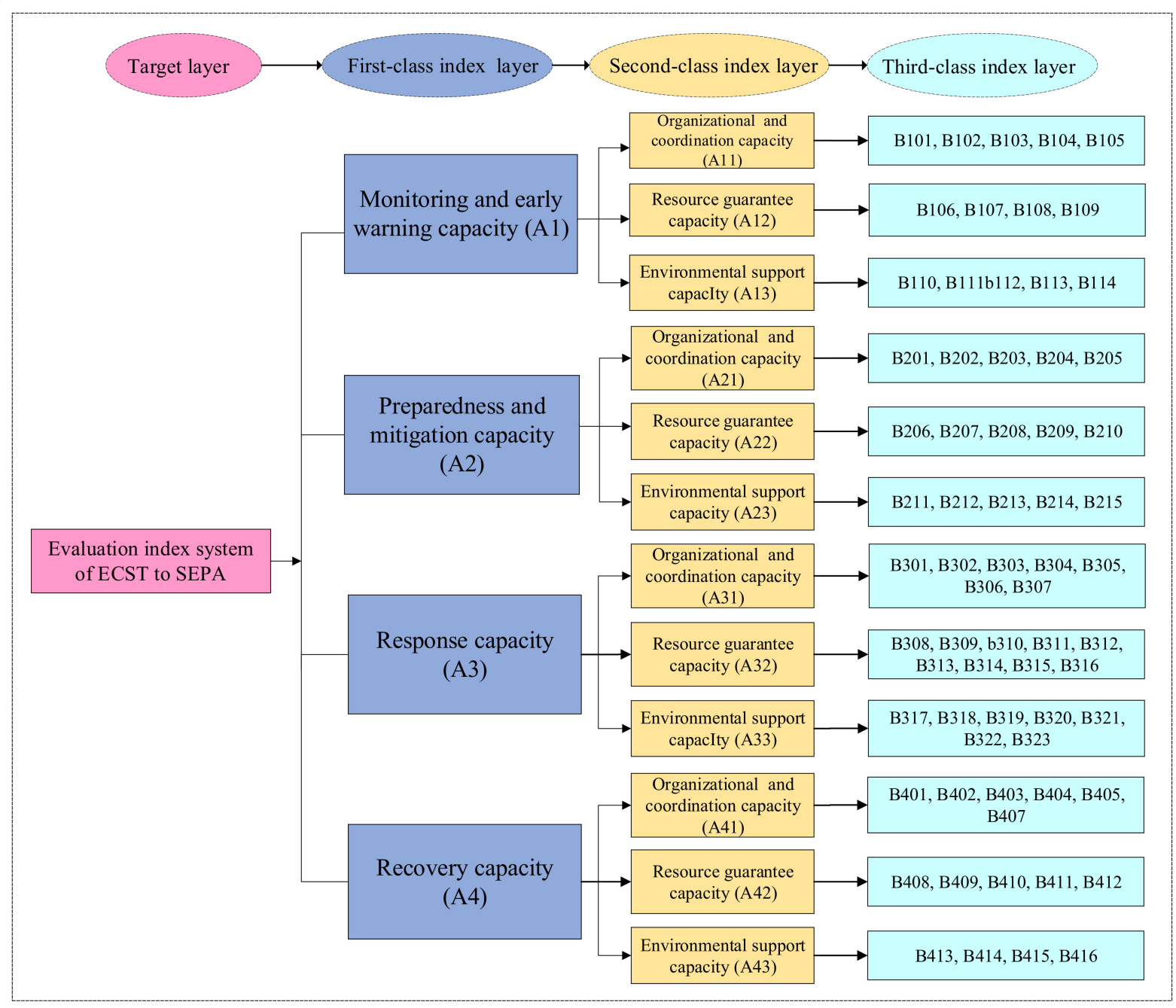

Figure 4. Hierarchical organization of the indexes. 
Table 2. Third-class indexes and symbols.

\begin{tabular}{|c|c|c|c|}
\hline Index & Symbol & Index & Symbol \\
\hline Clarity of the responsibilities of the monitor & B101 & Quantity of risk monitoring equipment & B108 \\
\hline Adequacy of shared monitoring information & B102 & Proportion of professional monitors & B109 \\
\hline Effectiveness of pollution route screening & B103 & Effectiveness of incident reporting process & B110 \\
\hline Effectiveness of investigation of major pollution sources & B104 & Perfection of emergency rules and regulations & B111 \\
\hline Timeliness of early warning information transmission & B105 & Broadcast and media level before the accident & B112 \\
\hline Development level of monitoring technology & B106 & $\begin{array}{c}\text { Soundness of the emergency management } \\
\text { organization }\end{array}$ & B113 \\
\hline Accuracy of equipment monitoring results & B107 & Validity of alarm program & B114 \\
\hline Propaganda and presentation skills to the public & B201 & Reserve guarantee of emergency resources & B209 \\
\hline Emergency preparedness drill level & B202 & Number of environmental supervisors & B210 \\
\hline Effectiveness of hazard source monitoring & B203 & $\begin{array}{c}\begin{array}{c}\text { Environmental protection knowledge level of } \\
\text { supervisor }\end{array}\end{array}$ & B211 \\
\hline Frequency of emergency training & B204 & Traffic control level & B212 \\
\hline Self-help knowledge education level & B205 & Coverage of emergency management agencies & B213 \\
\hline Number of emergency professionals & B206 & Coverage of emergency plans & B214 \\
\hline Shelter area & B207 & Regional population density & B215 \\
\hline Amount of government emergency funds & B208 & & \\
\hline Evacuation speed of organized rescue & B301 & $\begin{array}{c}\text { Comprehensiveness of the accident case } \\
\text { database }\end{array}$ & B313 \\
\hline Accuracy of accident development trend judgment & B302 & Number of decision command personnel & B314 \\
\hline Pertinence of emergency rescue work & B303 & Effectiveness of the expert support system & B315 \\
\hline $\begin{array}{c}\text { Effectiveness of secondary disaster monitoring } \\
\text { information }\end{array}$ & B304 & $\begin{array}{c}\text { Coverage rate of emergency command technical } \\
\text { system }\end{array}$ & B316 \\
\hline Effectiveness of dynamic monitoring of pollution range & B305 & Health care capacity & B317 \\
\hline Validity of situation assessment & B306 & Reporting speed of accident rescue progress & B318 \\
\hline $\begin{array}{c}\text { Coordination degree between command and other } \\
\text { departments }\end{array}$ & B307 & Broadcast media level in the accident & B319 \\
\hline Investment level of rescue equipment & B308 & $\begin{array}{c}\text { Unobstructed degree of the emergency resource } \\
\text { inquiry system }\end{array}$ & B320 \\
\hline Medical security capability & B309 & Coverage rate of emergency command sites & B321 \\
\hline Proportion of emergency professionals & B310 & $\begin{array}{l}\text { Soundness of established emergency response } \\
\text { system }\end{array}$ & B322 \\
\hline Speed of replenishment of relief supplies & B311 & Implementation degree of emergency plan & B323 \\
\hline Speed of relief materials allocation & B312 & & \\
\hline Validity of accident development trend analysis & B401 & Effectiveness of social insurance and assistance & B409 \\
\hline Casualty statistics capability & B402 & Compliance of fund use audit system & B410 \\
\hline Accident mechanism summary ability & B403 & $\begin{array}{l}\text { Validity of the establishment of psychological } \\
\text { counseling and relief stations }\end{array}$ & B411 \\
\hline Investigate and assess capacity of accident losses & B404 & $\begin{array}{c}\text { Long-term effect of government investment } \\
\text { system }\end{array}$ & B412 \\
\hline Responsibility degree for the accident & B405 & $\begin{array}{l}\text { Relationship maintaining with government and } \\
\text { non-governmental organizations }\end{array}$ & B413 \\
\hline Emergency resource integration capability & B406 & $\begin{array}{c}\text { Perfection level of the information feedback } \\
\text { system }\end{array}$ & B414 \\
\hline Emergency management and control level & B407 & $\begin{array}{l}\text { Implementation level of supervision and } \\
\text { prevention right of the supervision department }\end{array}$ & B415 \\
\hline Emergency funds reserve level & B408 & Recovery degree of water, electricity, and gas & B416 \\
\hline
\end{tabular}

\subsubsection{The ANP Method}

Considering that there were certain interactions between various evaluation indexes, we selected the ANP method for index weighting, as it is applicable for structuring the interactions between indexes. Then, we used Super Decision (SD) software for index weight calculation to obtain a more scientific and accurate weighting result. The ANP method is one of the most important methods used in research on objective decision-making. It not only maintains the hierarchical structure of the AHP and systematizes complex problems, but it also considers the mutual influence and coupling of various elements in a complex 
dynamic system [42,43]. This relationship includes the feedback of the lower element to the upper element and the interaction between the elements of the same layer. ANP divides the system elements into two major layers, namely, the control layer and the network layer, whose conceptual structures are shown in Figure 5. In summary, ANP fully considers the dependency and feedback among indexes to determine index weighting, which is more in line with the actual situations involved in decision-making processes. Therefore, the ANP method is especially suitable for complex systems with interdependent feedback relationships. At present, this method has been applied in many fields of evaluation and decision research $[44,45]$.

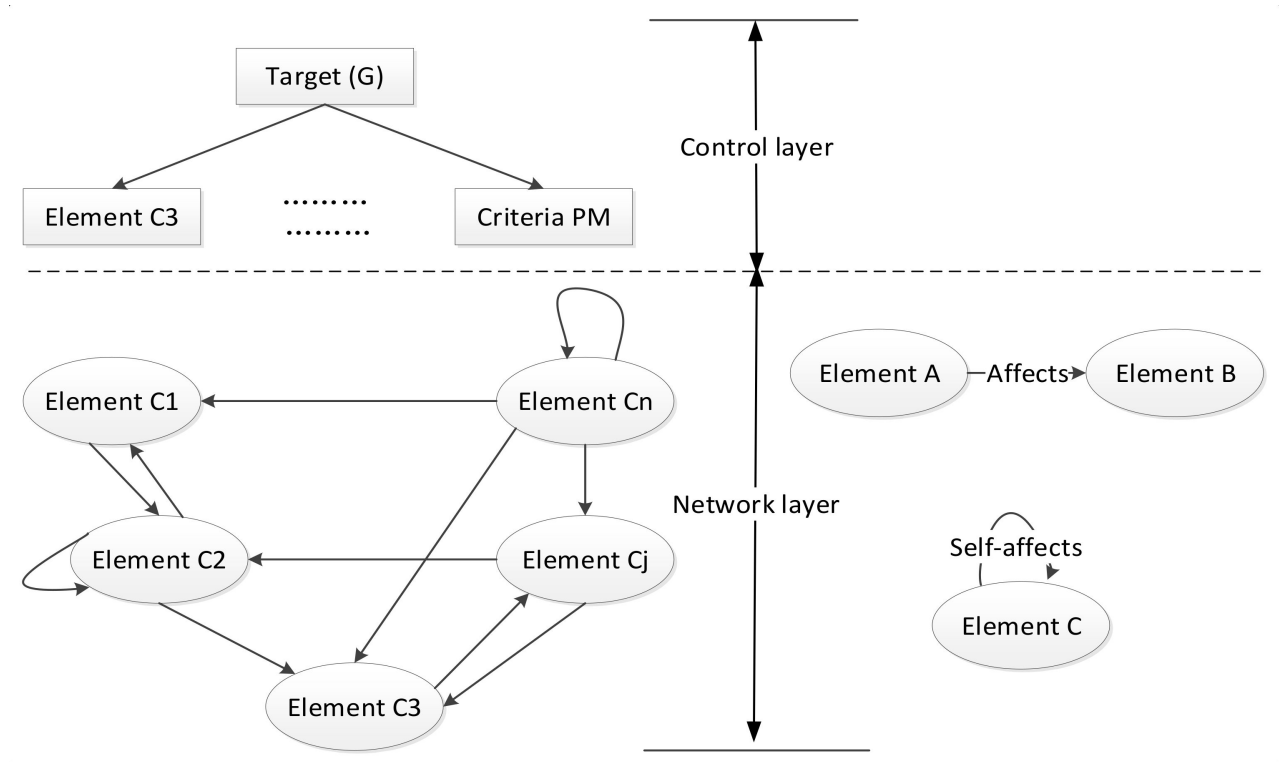

Figure 5. Conceptual hierarchy structure model of the ANP method.

We used the ANP method to weigh and calculate each index. The specific steps are as follows:

Step 1: An important step in AHP is to obtain a judgment matrix by pairwise comparison of the dominant elements under a certain criterion. However, in ANP, the elements to be compared may be interdependent, so the comparison must be carried out in two ways. One is direct dominance, that is, given a criterion, the two elements will compare the importance of the criterion. The second is the degree of indirect dominance, that is, a criterion is given under which the two elements compare the influence of a third element (called the sub-criterion). The former comparison applies to the case of independent elements, which is the traditional AHP comparison method. The latter comparison is more applicable when elements are interdependent, and this is where ANP and AHP differ.

Step 2: Build an unweighted supermatrix. According to the rules of ANP, experts and scholars in the field of enterprise emergency management were encouraged to use a first-class index as the benchmark to judge the relative importance among its secondclass indexes and construct a judgment matrix. Then, using the second-class index as the judgment standard, pairwise comparisons were made for the relative importance among the third-class indexes, and then a consistency test was carried out to obtain the normalized feature vectors. The vectors were summed to obtain the unweighted supermatrix $W_{S}$, as shown in Equation (1), where $W_{i j}$ represents the weight block matrix of the third-class index.

$$
W_{S}=\left[\begin{array}{cccc}
w_{11} & w_{12} & \cdots & w_{1 n} \\
w_{21} & w_{22} & \cdots & w_{2 n} \\
\vdots & \vdots & \ddots & \vdots \\
w_{n 1} & w_{n 2} & \cdots & w_{n n}
\end{array}\right]
$$


Step 3: Build the weight supermatrix. Taking the second-class index as the judgment standard, a paired comparison of the third-class index was used to construct the judgment matrix $A_{j}$. Normalization processing was performed to obtain the normalized eigenvector and the weight matrix $A_{S}$ reflecting the index relationship. Finally, the obtained weight matrix $A_{S}$ was multiplied by the unweighted supermatrix $W_{S}$ obtained in Step 2 to obtain the weighted supermatrix $W_{S}^{W}$, where $\lambda_{i j}$ represents the weight of the third-class index.

$$
\begin{aligned}
A_{S} & =\left[\begin{array}{cccc}
\lambda_{11} & \lambda_{12} & \cdots & \lambda_{1 n} \\
\lambda_{21} & \lambda_{22} & \cdots & \lambda_{2 n} \\
\vdots & \vdots & \ddots & \vdots \\
\lambda_{n 1} & \lambda_{n 2} & \cdots & \lambda_{n n}
\end{array}\right] \\
W_{S}^{W}=W_{S} A_{S}= & {\left[\begin{array}{cccc}
w_{11} \lambda_{11} & w_{12} \lambda_{12} & \cdots & w_{1 n} \lambda_{1 n} \\
w_{21} \lambda_{21} & w_{22} \lambda_{22} & \cdots & w_{2 n} \lambda_{2 n} \\
\vdots & \vdots & \ddots & \vdots \\
w_{n 1} \lambda_{n 1} & w_{n 2} \lambda_{n 2} & \cdots & w_{n n} \lambda_{n n}
\end{array}\right] }
\end{aligned}
$$

Step 4: Solve the limiting supermatrix. The weighted supermatrix obtained above was stabilized, that is, the computer limited relative sorting vector $W_{S}^{L}$ was:

$$
W_{S}^{L}=\lim _{k \rightarrow \infty}\left(W_{S}^{W}\right)^{k}
$$

Step 5: Calculate index weights. All the actual survey results of the expert interviews were input into the SD software, and then the weight of each evaluation index was calculated by a weighted average of the data results.

Step 6: Obtain the evaluation results. The weight of each third-class index was multiplied by the raw score of the corresponding index, the sum of the evaluation results of the third-class indexes was multiplied by the weight of the subordinate second-class index, and the evaluation results of all the second-class indexes were summed to obtain the comprehensive evaluation score of the first-class index. Finally, the evaluation results of the first-class indexes were summed to obtain the final evaluation result.

\subsubsection{Index Weighting}

To systematically estimate the ECST to SEPAs, it was necessary to conduct index weighting after the construction of the index system. Given that the evaluation indexes are not completely independent of each other, there are certain interactions between the indexes. In this section, the evaluation model based on the ANP method was established by integrating the weighting criteria and the relationship between each index. Specifically, when using ANP for index weighting, it was necessary to make a paired comparison of the elements to obtain the judgment matrix, integrate the expert opinions obtained by the Delphi method, and perform calculations using the SD software. Finally, the weights of each second-class index and third-class index were obtained. The index weighting results are presented in Table 3. 
Table 3. The result of index weighting.

\begin{tabular}{|c|c|c|c|c|}
\hline First-Class Index & Second-Class Index & $\begin{array}{c}\text { Weight of the } \\
\text { Second-Class Index }\end{array}$ & Third-Class Index & $\begin{array}{l}\text { Weight of the } \\
\text { Third-Class Index }\end{array}$ \\
\hline \multirow{14}{*}{ A1 } & \multirow{5}{*}{ A11 } & \multirow{5}{*}{0.3578} & B101 & 0.0072 \\
\hline & & & B102 & 0.1071 \\
\hline & & & B103 & 0.0415 \\
\hline & & & B104 & 0.0409 \\
\hline & & & B105 & 0.1611 \\
\hline & \multirow{4}{*}{$\mathrm{A} 12$} & \multirow{4}{*}{0.2846} & B106 & 0.0782 \\
\hline & & & B107 & 0.1326 \\
\hline & & & B108 & 0.0559 \\
\hline & & & B109 & 0.0179 \\
\hline & \multirow{5}{*}{ A13 } & \multirow{5}{*}{0.3576} & B110 & 0.0796 \\
\hline & & & B111 & 0.0571 \\
\hline & & & B112 & 0.0819 \\
\hline & & & B113 & 0.0353 \\
\hline & & & B114 & 0.1037 \\
\hline \multirow{15}{*}{$\mathrm{A} 2$} & \multirow{5}{*}{ A21 } & \multirow{5}{*}{0.3745} & B201 & 0.0379 \\
\hline & & & B202 & 0.1839 \\
\hline & & & B203 & 0.0787 \\
\hline & & & B204 & 0.0508 \\
\hline & & & B205 & 0.0232 \\
\hline & \multirow{5}{*}{$\mathrm{A} 22$} & \multirow{5}{*}{0.3185} & B206 & 0.0741 \\
\hline & & & B207 & 0.0573 \\
\hline & & & B208 & 0.0781 \\
\hline & & & B209 & 0.0839 \\
\hline & & & B210 & 0.0251 \\
\hline & \multirow{5}{*}{ A23 } & \multirow{5}{*}{0.3330} & B211 & 0.0306 \\
\hline & & & B212 & 0.1429 \\
\hline & & & B213 & 0.0767 \\
\hline & & & B214 & 0.0568 \\
\hline & & & B215 & 0.0260 \\
\hline \multirow{23}{*}{ A3 } & \multirow{7}{*}{$\mathrm{A} 31$} & \multirow{7}{*}{0.3739} & B301 & 0.1315 \\
\hline & & & B302 & 0.0361 \\
\hline & & & B303 & 0.0375 \\
\hline & & & B304 & 0.0133 \\
\hline & & & B305 & 0.0242 \\
\hline & & & B306 & 0.0509 \\
\hline & & & B307 & 0.0804 \\
\hline & \multirow{9}{*}{ A32 } & \multirow{9}{*}{0.3015} & B308 & 0.0092 \\
\hline & & & B309 & 0.0097 \\
\hline & & & B310 & 0.0208 \\
\hline & & & B311 & 0.0249 \\
\hline & & & B312 & 0.0073 \\
\hline & & & B313 & 0.0565 \\
\hline & & & B314 & 0.0678 \\
\hline & & & B315 & 0.0569 \\
\hline & & & B316 & 0.0484 \\
\hline & \multirow{7}{*}{ A33 } & & B317 & 0.0082 \\
\hline & & & B318 & 0.0092 \\
\hline & & & B319 & 0.0661 \\
\hline & & 0.3246 & B320 & 0.0616 \\
\hline & & & B321 & 0.0642 \\
\hline & & & B322 & 0.0567 \\
\hline & & & B323 & 0.0586 \\
\hline
\end{tabular}


Table 3. Cont.

\begin{tabular}{|c|c|c|c|c|}
\hline First-Class Index & Second-Class Index & $\begin{array}{c}\text { Weight of the } \\
\text { Second-Class Index }\end{array}$ & Third-Class Index & $\begin{array}{l}\text { Weight of the } \\
\text { Third-Class Index }\end{array}$ \\
\hline \multirow{16}{*}{ A4 } & \multirow{7}{*}{ A41 } & \multirow{7}{*}{0.5348} & B401 & 0.0207 \\
\hline & & & B402 & 0.0281 \\
\hline & & & B403 & 0.019 \\
\hline & & & B404 & 0.1089 \\
\hline & & & B405 & 0.1173 \\
\hline & & & B406 & 0.1186 \\
\hline & & & B407 & 0.1222 \\
\hline & \multirow{5}{*}{ A42 } & \multirow{5}{*}{0.3099} & B408 & 0.0707 \\
\hline & & & B409 & 0.1074 \\
\hline & & & B410 & 0.0805 \\
\hline & & & B411 & 0.0513 \\
\hline & & & B412 & 0.0461 \\
\hline & \multirow{4}{*}{ A43 } & \multirow{4}{*}{0.1553} & B413 & 0.0084 \\
\hline & & & B414 & 0.0325 \\
\hline & & & B415 & 0.0596 \\
\hline & & & B416 & 0.0087 \\
\hline
\end{tabular}

\section{Results and Discussion}

\subsection{Application}

3.1.1. A Typical Case

Jiangyin City is located in the south of Jiangsu Province, China, and is a county-level city subordinate to the prefecture-level city of Wuxi. It is located in the geometric center of the "golden triangle of Su-Xi-Chang" area, with a developed economy and superior transportation location. Its geographical distribution is shown in Figure 6. At the end of 2019, the permanent resident population of Jiangyin was 1.6535 million, the urbanization rate was $71.63 \%$, and the regional GDP was CNY 40.0112 billion, of which the industrial output value was CNY 185.155 billion, accounting for $46 \%$ [46]. The reasons for choosing Jiangyin City as the study case was influenced by three aspects. First, Jiangyin City is located in the Yangtze River basin, with abundant water bodies and frequent waterway transportation, which makes the risk of SEPAs caused by safety accidents, traffic accidents, influent water from the upper reaches of the Yangtze River, or hazardous waste dumping relatively high. Second, the rapid economic growth of Jiangyin City mainly depends on the extensive development and the consumption of land resources, raw materials, and energy is huge. Recent adjustments have optimized the city's industrial structure to some extent, but the proportion of industry, especially high-pollution industries such as textile printing and dyeing, chemical, and metallurgy, is still too high. These enterprises have a high risk of SEPAs, which cause negative impacts and huge losses to the environment and economy. Third, since Jiangyin City has had several serious SEPAs (e.g., styrene leakage accident at Jiasheng Terminal on 15 March 2011, and the chlorinated benzene overturning accident on Xicheng Expressway on 14 July 2012), Jiangyin Municipal Government, together with the relevant departments of environmental protection, traffic, and safety supervision, issued the "Jiangyin Municipal Emergency Plan for Emergent Environmental Events" and formulated a series of emergency management measures. However, there are still some shortcomings regarding the enforcement process, and it is necessary to further perfect the emergency management measures of the government and emergency departments based on the assessment of the current emergency capacity. 


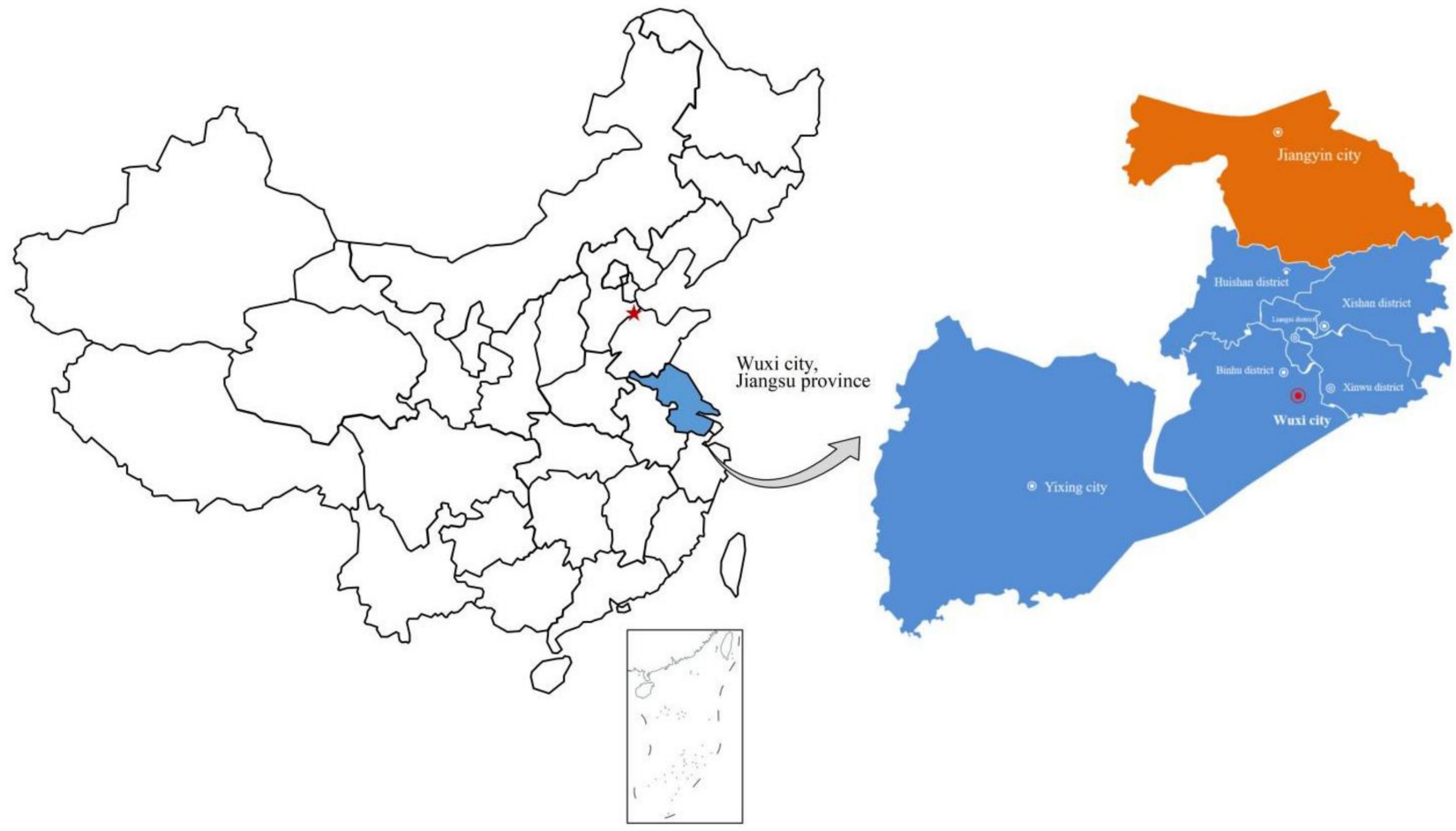

Figure 6. Geographical distribution of Jiangyin City.

Overall, with the rapid development of the economy occurring under the background of the internal requirements of government transformation, industrial structure adjustment, and the construction of a "Riverside Garden" city, Jiangyin City is faced with many environmental risk factors. SEPAs occur often, and the environmental safety situation is not optimistic. Therefore, Jiangyin City, as one of China's county-level economies who relies on industrial development, systematic evaluation, and judgment of its SEPA emergency capacity, is significant. It must figure out its current emergency management ability to provide a scientific reference for developing targeted management policies and mitigation measures for SEPAs. Finally, the city can be a typical reference for other cities along the Yangtze River Basin to optimize their emergency management systems.

\subsubsection{Raw Data}

Through the field investigation of the current emergency management status, the summary of previous experience dealing with SEPAs in Jiangyin City, and references to the city statistical yearbook, literature, state laws, and regulations such as The National Emergency Plan for Environmental Emergencies, the Law on Emergency Management of Environmental Emergencies, and the Law of the People's Republic of China on Response to Emergencies, the raw data of each index were obtained. Then, the raw data were scored according to the scoring standard of the 68 third-class indexes (see Appendix A), and the scores of each index were finally acquired, as shown in Table 4.

Table 4. Collection and scores of the raw data.

\begin{tabular}{ccccc}
\hline $\begin{array}{c}\text { Third-Classes } \\
\text { Index }\end{array}$ & Raw Data & Score & $\begin{array}{c}\text { Third-Classes } \\
\text { Index }\end{array}$ & Raw Data \\
\hline B101 & Genera effect, clear & 0.5 & B108 & Very good effect, very well equipped \\
B102 & Good effect, relative adequate & 0.8 & B109 & High proportion \\
B103 & Good effect, high investment & 0.8 & B110 & General effect, general sound \\
B104 & Very good effect, very high investment & 1.0 & B111 & Very good \\
B105 & Good effect, relatively timely & 0.8 & B112 & General effect, general level \\
B106 & Good effect, high level & 0.8 & B113 & General effect, general sound \\
B107 & Good effect, relatively accurate & 0.8 & B114 & High investment, good effect \\
\hline
\end{tabular}


Table 4. Cont.

\begin{tabular}{|c|c|c|c|c|c|}
\hline $\begin{array}{l}\text { Third-Classes } \\
\text { Index }\end{array}$ & Raw Data & Score & $\begin{array}{l}\text { Third-Classes } \\
\text { Index }\end{array}$ & Raw Data & Score \\
\hline B201 & Very good effect & 1.0 & B209 & General investment, general guarantee & 0.6 \\
\hline B202 & At least once a year & 1.0 & B210 & Large number & 0.8 \\
\hline B203 & Good effect, high investment & 0.8 & B211 & High level & 0.8 \\
\hline B204 & $\begin{array}{l}\text { Very high investment, very high } \\
\text { frequency }\end{array}$ & 1.0 & $\mathrm{~B} 212$ & High investment, very high level & 1.0 \\
\hline B205 & High level & 0.8 & B213 & $\begin{array}{l}\text { Very high investment, very high } \\
\text { coverage rate }\end{array}$ & 1.0 \\
\hline B206 & General investment, large number & 0.8 & B214 & $\begin{array}{l}\text { Very high investment, very high } \\
\text { coverage rate }\end{array}$ & 1.0 \\
\hline $\begin{array}{l}\text { B207 } \\
\text { B208 }\end{array}$ & $\begin{array}{c}\text { General area } \\
\text { Very high investment }\end{array}$ & $\begin{array}{l}0.6 \\
1.0\end{array}$ & B215 & General density & 0.6 \\
\hline B301 & Very high speed & 0.8 & B313 & $\begin{array}{l}\text { High investment, relatively } \\
\text { comprehensive }\end{array}$ & 0.8 \\
\hline B302 & General accuracy & 0.6 & B314 & Large number & 0.8 \\
\hline B303 & Very good effect, very high pertinence & 1.0 & B315 & General effect, general validity & 0.6 \\
\hline B304 & General effect, general validity & 0.6 & B316 & $\begin{array}{l}\text { General investment, general coverage } \\
\text { rate }\end{array}$ & 0.6 \\
\hline B305 & Good effect, high validity & 0.8 & B317 & High investment, good guarantee & 0.8 \\
\hline B306 & Very good effect, very high validity & 1.0 & B318 & Very good effect, very high speed & 1.0 \\
\hline B307 & Good effect, high coordination degree & 0.8 & B319 & Very high investment, very high level & 0.8 \\
\hline B308 & High investment, high level & 0.8 & B320 & $\begin{array}{l}\text { High investment, high unobstructed } \\
\text { degree }\end{array}$ & 0.8 \\
\hline B309 & High investment, high support capacity & 0.8 & B321 & $\begin{array}{l}\text { General investment, general coverage } \\
\text { rate }\end{array}$ & 0.6 \\
\hline B310 & High proportion & 0.8 & B322 & General investment, relatively sound & 0.8 \\
\hline B311 & Very good effect, very high speed & 1.0 & B323 & $\begin{array}{c}\text { General effect, general implementation } \\
\text { degree }\end{array}$ & 0.6 \\
\hline B312 & Very good effect, very high speed & 1.0 & & & \\
\hline B401 & General effect, general validity & 0.6 & B409 & Good effect, good validity & 0.8 \\
\hline B402 & Very good effect & 1.0 & B410 & Very good effect, very reasonable & 1.0 \\
\hline B403 & Very high ability & 1.0 & B411 & General effect, general validity & 0.4 \\
\hline B404 & Good effect & 0.8 & B412 & High investment, high validity & 0.8 \\
\hline B405 & $\begin{array}{l}\text { Very good effect, very high } \\
\text { implementation degree }\end{array}$ & 1.0 & B413 & Good effect & 0.8 \\
\hline B406 & High ability & 0.8 & B414 & $\begin{array}{l}\text { High investment, relatively high } \\
\text { perfection level }\end{array}$ & 0.8 \\
\hline B407 & High level & 0.8 & B415 & $\begin{array}{c}\text { Good effect, high implementation } \\
\text { degree }\end{array}$ & 0.7 \\
\hline HB408 & High level & 0.8 & B416 & $\begin{array}{l}\text { Very high investment, very high } \\
\text { recovery degree }\end{array}$ & 1.0 \\
\hline
\end{tabular}

\subsection{Evaluation Result and Discussion}

According to step 6 of the ANP method, the evaluation scores of the indexes in the three classes were calculated. The comprehensive evaluation results of the emergency capacity in various stages of the SEPA life cycle in Jiangyin City are shown in Table 5.

Figure 7 shows the emergency capability performance of Jiangyin City in four different dimensions: monitoring and early warning capacity (A1), preparedness and mitigation capacity (A2), response capacity (A3), and recovery capacity (A4). It can be seen from the comparative analysis that the evaluation score of A4 was the highest, followed by $\mathrm{A} 2$, both of which were above 0.8 . The evaluation score of A3 was slightly lower than 0.8 , and A1 was the lowest among the four dimensions. These results indicate that Jiangyin City has a certain heterogeneity in the different stages of its emergency management capacity to SEPAs. Its monitoring and early warning capacity and response capacity are relatively weak, but it has strong preparedness, mitigation capacity, and recovery capacity. This may be because the occurrence of a SEPA usually has great randomness and uncertainty, and the monitoring and forecasting information available to emergency managers is weak when there is a lack of certainty of causality or evidence of an emergency. As a result, the government and relevant emergency departments have difficulty identifying the type and condition of 
the sudden accident and thus cannot make scientific and accurate contingency plans for response and disposal, which also explains the reason for their weak response ability.

Table 5. Evaluation results.

\begin{tabular}{|c|c|c|c|c|c|}
\hline $\begin{array}{l}\text { First-Class } \\
\text { Index }\end{array}$ & $\begin{array}{l}\text { Evaluation Score of } \\
\text { the First-Class Index }\end{array}$ & $\begin{array}{l}\text { Second-Class Index } \\
\text { (Weight) }\end{array}$ & $\begin{array}{l}\text { Evaluation Score of the } \\
\text { Second-Class Index }\end{array}$ & $\begin{array}{l}\text { Third-Class Index } \\
\text { (Weight) }\end{array}$ & $\begin{array}{c}\text { Evaluation Score of } \\
\text { the Third-Class } \\
\text { Index }\end{array}$ \\
\hline \multirow{3}{*}{$\mathrm{A} 1$} & \multirow{3}{*}{0.7822} & $\begin{array}{c}\mathrm{A} 11 \\
(0.3578)\end{array}$ & 0.8168 & $\begin{array}{l}\text { B101 }(0.0072) \\
\text { B102 }(0.1071) \\
\text { B103 }(0.0415) \\
\text { B104 }(0.0409) \\
\text { B105 }(0.1611)\end{array}$ & $\begin{array}{l}0.5 \\
0.8 \\
0.8 \\
1.0 \\
0.8\end{array}$ \\
\hline & & $\begin{array}{c}\mathrm{A} 12 \\
(0.2846)\end{array}$ & 0.8267 & $\begin{array}{l}\text { B106 }(0.0782) \\
\text { B107 }(0.1326) \\
\text { B108 }(0.0559) \\
\text { B109 }(0.0179)\end{array}$ & $\begin{array}{l}0.8 \\
0.8 \\
1.0 \\
0.6\end{array}$ \\
\hline & & $\begin{array}{c}\mathrm{A} 13 \\
(0.3576)\end{array}$ & 0.7120 & $\begin{array}{l}\text { B110 }(0.0796) \\
\text { B111 }(0.0571) \\
\text { B112 }(0.0819) \\
\text { B113 }(0.0353) \\
\text { B114 }(0.1037)\end{array}$ & $\begin{array}{l}0.6 \\
1.0 \\
0.6 \\
0.5 \\
0.8\end{array}$ \\
\hline \multirow{3}{*}{$\mathrm{A} 2$} & \multirow{3}{*}{0.8118} & $\begin{array}{c}\mathrm{A} 21 \\
(0.3745)\end{array}$ & 0.8087 & $\begin{array}{l}\text { B201 }(0.0379) \\
\text { B202 }(0.1839) \\
\text { B203 }(0.0787) \\
\text { B204 }(0.0508) \\
\text { B205 }(0.0232)\end{array}$ & $\begin{array}{l}1.0 \\
0.9 \\
0.8 \\
1.0 \\
0.8\end{array}$ \\
\hline & & $\begin{array}{c}\mathrm{A} 22 \\
(0.3185)\end{array}$ & 0.6041 & $\begin{array}{l}\text { B206 }(0.0741) \\
\text { B207 }(0.0573) \\
\text { B208 }(0.0781) \\
\text { B209 }(0.0839) \\
\text { B210 }(0.0251)\end{array}$ & $\begin{array}{l}0.8 \\
0.6 \\
1.0 \\
0.6 \\
0.8\end{array}$ \\
\hline & & $\begin{array}{c}\mathrm{A} 23 \\
(0.3330)\end{array}$ & 0.9503 & $\begin{array}{l}\text { B211 }(0.0306) \\
\text { B212 }(0.1429) \\
\text { B213 }(0.0767) \\
\text { B214 }(0.0568) \\
\text { B215 }(0.0260)\end{array}$ & $\begin{array}{l}0.8 \\
1.0 \\
1.0 \\
1.0 \\
0.6\end{array}$ \\
\hline \multirow{3}{*}{$\mathrm{A} 3$} & \multirow{3}{*}{0.7705} & $\begin{array}{c}\mathrm{A} 31 \\
(0.3739)\end{array}$ & 0.8209 & $\begin{array}{l}\text { B301 }(0.1315) \\
\text { B302 }(0.0361) \\
\text { B303 }(0.0375) \\
\text { B304 }(0.0133) \\
\text { B305 }(0.0242) \\
\text { B306 }(0.0509) \\
\text { B307 }(0.0804)\end{array}$ & $\begin{array}{l}0.8 \\
0.6 \\
1.0 \\
0.6 \\
0.8 \\
1.0 \\
0.8\end{array}$ \\
\hline & & $\begin{array}{c}\mathrm{A} 32 \\
(0.3015)\end{array}$ & 0.7515 & $\begin{array}{l}\text { B308 }(0.0092) \\
\text { B309 }(0.0097) \\
\text { B310 }(0.0208) \\
\text { B311 }(0.0249) \\
\text { B312 }(0.0073) \\
\text { B313 }(0.0565) \\
\text { B314 }(0.0678) \\
\text { B315 }(0.0569) \\
\text { B316 }(0.0484)\end{array}$ & $\begin{array}{l}0.8 \\
0.8 \\
0.8 \\
1.0 \\
1.0 \\
0.8 \\
0.8 \\
0.6 \\
0.6\end{array}$ \\
\hline & & $\begin{array}{c}\mathrm{A} 33 \\
(0.3246)\end{array}$ & 0.7300 & $\begin{array}{l}\text { B317 }(0.0082) \\
\text { B318 }(0.0092) \\
\text { B319 }(0.0661) \\
\text { B320 }(0.0616) \\
\text { B321 }(0.0642) \\
\text { B322 }(0.0567) \\
\text { B323 }(0.0586)\end{array}$ & $\begin{array}{l}0.8 \\
1.0 \\
0.8 \\
0.8 \\
0.6 \\
0.8 \\
0.6\end{array}$ \\
\hline
\end{tabular}


Table 5. Cont.

\begin{tabular}{|c|c|c|c|c|c|}
\hline $\begin{array}{l}\text { First-Class } \\
\text { Index }\end{array}$ & $\begin{array}{c}\text { Evaluation Score } \\
\text { of the First-Class } \\
\text { Index }\end{array}$ & $\begin{array}{l}\text { Second-Class } \\
\text { Index (Weight) }\end{array}$ & $\begin{array}{c}\text { Evaluation Score of } \\
\text { the Second-Class } \\
\text { Index }\end{array}$ & $\begin{array}{l}\text { Third-Class Index } \\
\text { (Weight) }\end{array}$ & $\begin{array}{c}\text { Evaluation Score } \\
\text { of the Third-Class } \\
\text { Index }\end{array}$ \\
\hline \multirow{3}{*}{$\mathrm{A} 4$} & \multirow{3}{*}{0.8201} & $\begin{array}{c}\text { A41 } \\
(0.5348)\end{array}$ & 0.8537 & $\begin{array}{l}\text { B401 }(0.0207) \\
\text { B402 }(0.0281) \\
\text { B403 }(0.0190) \\
\text { B404 }(0.1089) \\
\text { B405 }(0.1173) \\
\text { B406 }(0.1186) \\
\text { B407 }(0.1222)\end{array}$ & $\begin{array}{l}0.6 \\
1.0 \\
1.0 \\
0.8 \\
1.0 \\
0.8 \\
0.8\end{array}$ \\
\hline & & $\begin{array}{c}\text { A42 } \\
(0.3099)\end{array}$ & 0.7857 & $\begin{array}{l}\text { B408 }(0.0707) \\
\text { B409 }(0.1074) \\
\text { B410 }(0.0805) \\
\text { B411 }(0.0513)\end{array}$ & $\begin{array}{l}0.8 \\
0.8 \\
1.0 \\
0.4\end{array}$ \\
\hline & & $\begin{array}{c}\text { A43 } \\
(0.1553)\end{array}$ & 0.7728 & $\begin{array}{l}\text { B412 }(0.0461) \\
\text { B413 }(0.0084) \\
\text { B414 }(0.0325) \\
\text { B415 }(0.0596) \\
\text { B416 }(0.0087)\end{array}$ & $\begin{array}{l}0.8 \\
0.8 \\
0.8 \\
0.7 \\
1.0\end{array}$ \\
\hline
\end{tabular}

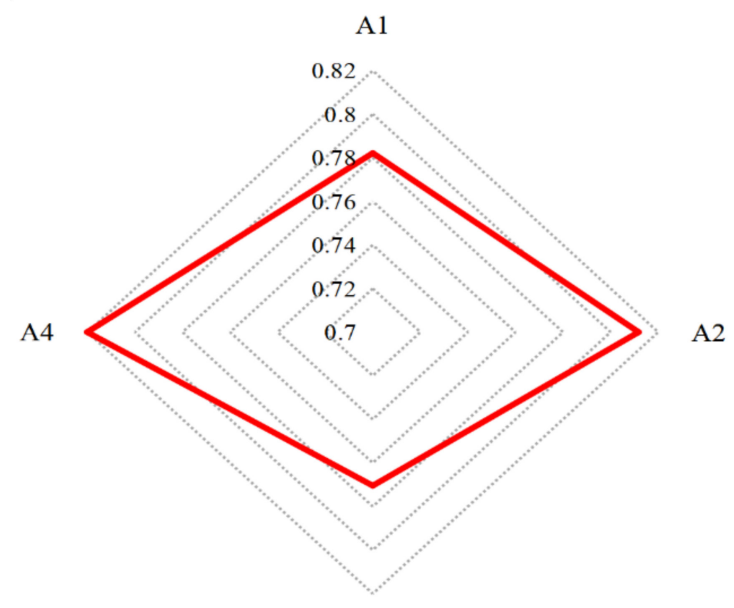

$\mathrm{A} 3$

Figure 7. Evaluation results of the first-class indexes (Notes: A1 means monitoring and early warning capacity, A2 means preparedness and mitigation capacity, A3 means response capacity, and A4 means recovery capacity.).

According to Table 5, Figures 8 and 9, further analysis of the evaluation results of the third-class indexes shows the following:

First, in terms of monitoring and early warning capacity (A1), the evaluation scores of organizational and coordination ability and resource and guarantee ability were both above 0.8 , while the evaluation score of environmental support ability was only 0.712 . From the third-class indexes of the environment supporting capacity of A1, the evaluation scores of three indexes, the effectiveness of the incident reporting process (B110), the broadcast media level before the accident (B112), and the soundness of the emergency management organization (B113), were between 0.5 and 0.6 , which is an average level. This indicates that Jiangyin City has low work efficiency and media investment in the reporting process of SEPAs, so it is likely to miss the best period of emergency accident treatment. Although Jiangyin City has an emergency office, its emergency management functions are not perfect. After a SEPA occurred, a temporary emergency work team was formed by drawing staff from relevant emergency departments. When the accident was dealt with, the temporary work team was disbanded, the workers returned to their original posts, and the relevant 
information about the emergency was dispersed across the archives of various departments, which led to a lack of coordination and professionalism in the work organization. Thus, the health of the emergency management organization and coordination in Jiangyin City still needs to be greatly optimized.

Second, in terms of preparedness and mitigation capacity (A2), the evaluation score of the resource guarantee capacity was only 0.6041 , which is at a general level. The weight of this second-class index was 0.3285 , which was less than the weight of the other two secondclass indexes, indicating that the importance and attention of resource guarantee ability are relatively low in the preparation and mitigation stages of a SEPA. In the corresponding third-class indexes, the evaluation scores of shelter area (B207) and reserve guarantee of emergency resources (B209) were both 0.6, indicating that Jiangyin City is not fully prepared in terms of having emergency refuges and resources. Due to the small land area, large population, and compact urban buildings in Jiangyin City, there are few parks and areas that can be used as shelters. At the same time, Jiangyin City also lacks professional equipment and sufficient materials, which indicates that the government should construct and invest in resource support capacity, which would improve the city's preparedness and mitigation capacity for emergencies.

Third, in terms of emergency response capacity, the evaluation scores of the resource guarantee ability and the environmental support ability were both lower than 0.8 . According to the evaluation scores of the corresponding third-class indexes, only the evaluation scores of the effectiveness of the expert support system (B315), coverage rate of emergency command technical system (B316), coverage rate of emergency command sites (B321), and implementation degree of the emergency plan (B323) were 0.6 , while the others were above 0.8 . This is mainly because the weights of the resource guarantee ability and the environmental support ability were lower than that of the organization and coordination ability. Environmental pollution accidents are different from natural disasters such as earthquakes. A SEPA may occur in areas with a large number of residents, so the most important work for SEPA management is that which addresses the pollution itself. Therefore, the effectiveness and timeliness of emergency situation assessment must be given much attention.

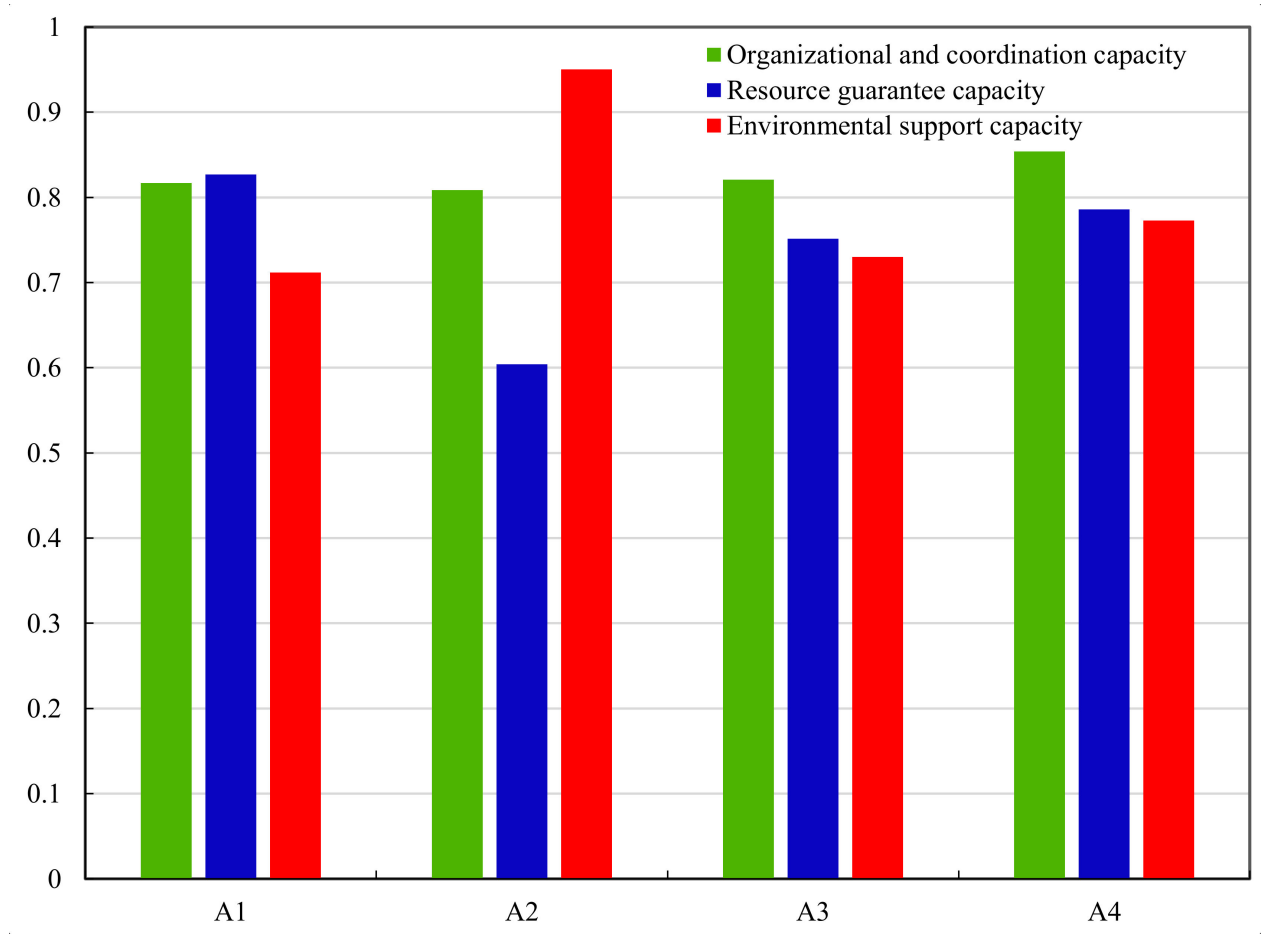

Figure 8. Evaluation results of the second-class indexes (Notes: A1 means monitoring and early warning capacity, $\mathbf{A} \mathbf{2}$ means preparedness and mitigation capacity, A3 means response capacity, and A4 means recovery capacity.). 

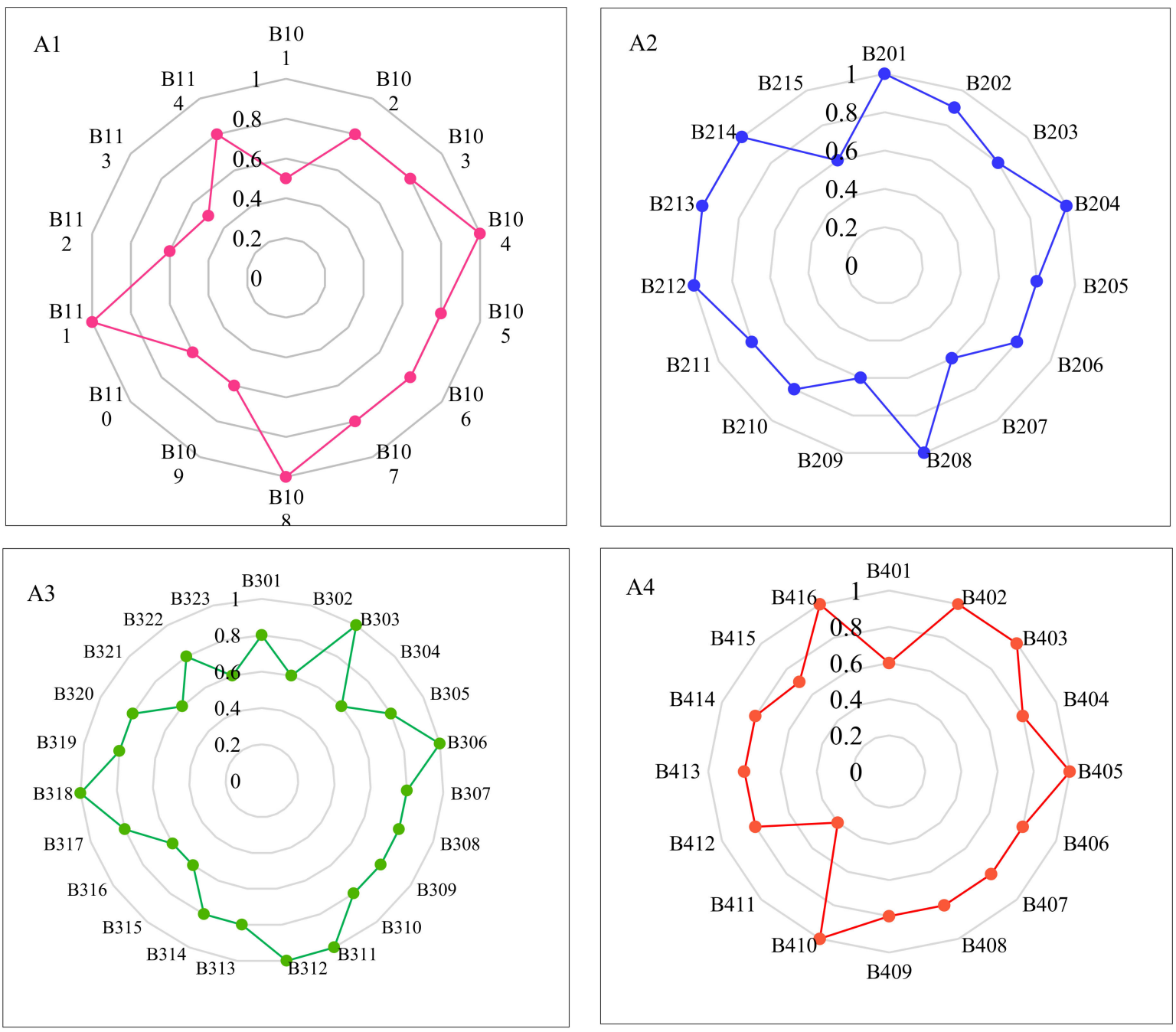

Figure 9. Evaluation results of the third-class indexes (Notes: A1 means monitoring and early warning capacity, A2 means preparedness and mitigation capacity, A3 means response capacity, and A4 means recovery capacity.).

Finally, in terms of recovery capacity, the evaluation result of the organization and coordination capacity was higher than 0.85 , and its weight was 0.5438 , higher than the weights of the resource guarantee capacity and the environmental resources support capacity. From the third-class index, the weights of the four indexes for investigation and assessment of the capacity of accident losses (B404), degree of responsibility for the accident (B405), emergency resource integration capability (B406), and emergency management and control level (B407) were all above 0.1, indicating that these four indicators play a decisive role in the stage of restoration and reconstruction and should be given sufficient attention. Moreover, the evaluation scores of these four indexes were all above 0.8 , indicating that Jiangyin City has a sufficient system with respect to these indexes. However, the evaluation results of some indexes were very low. For example, the evaluation score of the validity of the establishment of psychological counseling and relief stations (B411) was only 0.4, which may be because SEPAs in Jiangyin have not occurred frequently or caused any panic, so the government and emergency departments have not paid enough attention to the psychological reconstruction of residents after the accidents.

The evaluation results show that the overall SEPA emergency capacity in Jiangyin City is good. In particular, the preparedness and mitigation capacity is relatively high, but there are still some weaknesses and defects in the emergency management system. For example, clear accident monitoring personnel responsibilities and psychological intervention of residents after the disaster still need to be given further attention. Generally speaking, the 
above evaluation results are consistent with the perceived evaluation results obtained by expert interviews and field investigations, verifying the validity of the evaluation model and the accuracy of the evaluation results.

\section{Conclusions and Policy Implications}

\subsection{Key Conclusions}

Emergency management capability evaluation is an important prerequisite for enhancing emergency management capability. Given the limited economic and environmental resources and the weak basis of emergency management systems in small towns, as well as the great complexity and uncertainty of SEPAs, the emergency work of enterprises and governments faces great challenges. Therefore, accurately evaluating and improving the ECST to SEPAs has important theoretical and practical significance. Based on the evolutionary mechanism of a SEPA, this study constructed a multi-dimensional index system and an evaluation model of the ECST to SEPAs based on the ANP method and the selected case study of Jiangyin City, China, which has a high risk of SEPAs. The main conclusions of this study are as follows:

First, the evolution mechanism of SEPAs was revealed. The evolutionary mechanism of SEPAs was systematically analyzed from four main scenarios: disaster-inducing factors, disaster-generating environment, disaster-bearing body, and the SEPA. The mechanism revealed that there were certain interactions and dependent feedback relationships among the factors that affected the occurrence and evolution of the SEPA, which provided a theoretical basis for the establishment of an evaluation index system and evaluation model.

Second, a multidimensional evaluation index system of the ECST to SEPAs based on the life cycle of an emergency was constructed. The index system included four firstclass indexes: monitoring and early warning, preparedness and mitigation, response, and resilience capacities, each of which was divided into second-class indexes of three dimensions: organization coordination, resource guarantee, and environmental support capacities. Finally, the index system contained 68 third-class indexes. Compared with the existing emergency capability evaluation index system, the constructed index system systematically covers four stages of emergency management from the perspective of the entire life cycle of accident occurrence. The selection of indexes in this system is more comprehensive and scientific, which helps to improve the effectiveness of the evaluation results of the ECST to SEPAs.

Finally, the evaluation model of the ECST to SEPAs based on the ANP method was proposed and applied in the case study area of Jiangyin City. The evaluation model considered the interaction between the indicators and the dependent feedback relationships, which strengthened the evaluation results. Moreover, the empirical evaluation results showed that Jiangyin has a relatively high level of preparedness mitigation capacity and recovery capacity to SEPAs, but its monitoring and warning capacity and response capacity still need to be further improved. These results were consistent with the actual situation of the emergency management of Jiangyin, which verified the effectiveness of the proposed evaluation model.

\subsection{Policy Implications}

Considering the development status and deficiencies of emergency management in small towns, based on the above research conclusions, we respectively put forward the following policy suggestions for the three stages before, during, and after the occurrence of SEPA:

First, in terms of pre-disaster prevention, SEPA is often highly uncertain and unpredictable, so it is very necessary to construct a scientific and effective emergency monitoring and early warning mechanism of SEPA with the help of emerging technologies. For the emergency management departments of small towns, the emergency management should gradually turn from the traditional passive defense to the active pre-warning. Specifically, on the one hand, a comprehensive and scientific monitoring and early warning index 
system for SEPA should be built according to local conditions. On the other hand, scientific and technological means such as big data, the Internet of Things, and geographical remote sensing can be rationally used to gradually form a working mechanism for disaster prevention and reduction drove by scientific and technological innovation.

Second, the causes of environmental events are complex and varied, so how to minimize the impact range and impact degree of the SEPA that has occurred is the focus of emergency response work. In terms of response work for SEPA, the local government of small towns should increase the investment in the improvement of organization and coordination capacity and resource guarantee capacity, strengthen the coordination, and liaison between emergency departments and environmental protection and safety departments, supervision departments, transportation departments, and other assisting units, so as to establish a long-term emergency response and linkage working mechanism.

Finally, the implementation of SEPA post-recovery is the last link to ensure environmental safety, but also the most easily neglected one. Make an objective and accurate assessment of the harm and damage scope of SEPA, scientifically predict the medium- and long-term impact of SEPA on the local environment, reasonably develop specific restoration and ecological compensation measures, and timely summarize the experience and lessons, so as to provide theoretical experience for the protection of environmental safety and stability in the future work.

\subsection{Limitations and Future Research}

There are many small towns in China and their characteristics are quite different. Obviously, the proposed evaluation indexes cannot be applied to all types of small towns. In future research, expanding the study sample should be considered. Specifically, the small towns with a high risk of sudden environmental pollution in China can be classified according to their characteristics and attributes, and the corresponding evaluation model could be constructed.

Author Contributions: D.W.: Conceptualization, visualization, supervision, review and editing. Y.W.: data curation, methodology, software, writing-original draft. Both authors have read and agreed to the published version of the manuscript.

Funding: This research was funded by the National Natural Science Foundation of China No. 71573252.

Institutional Review Board Statement: Not applicable.

Informed Consent Statement: Not applicable.

Data Availability Statement: The datasets used and/or analyzed during the current study are available from the corresponding author on reasonable request.

Acknowledgments: We thank the anonymous reviewers for their constructive comments for improving the paper.

Conflicts of Interest: The authors declare no conflict of interest.

\section{Appendix A}

(1) Clarity of the responsibilities of the monitor (B101)

$$
\mathrm{B} 101=\left\{\begin{array}{l}
\text { Very bad effect, very unclear } 0 \sim 0.2 \\
\text { Bad effect, unclear 0.2 0.4 } \\
\text { General effect, clear 0.4 0.6 } \\
\text { Good effect, relatively clear 0.6 0.8 } \\
\text { Very good effect, very clear } 0.8 \sim 1
\end{array}\right.
$$


(2) Adequacy of shared monitoring information (B102)

$$
\mathrm{B} 102=\left\{\begin{array}{l}
\text { Very bad effect, very inadequate } 0 \sim 0.2 \\
\text { Bad effect, inadequate } 0.2 \sim 0.4 \\
\text { General effect, adequate } 0.4 \sim 0.6 \\
\text { Good effect, relatively adequate } 0.6 \sim 0.8 \\
\text { Very good effect, very adequate } 0.8 \sim 1
\end{array}\right.
$$

(3) Effectiveness of pollution route screening (B103)

$$
\mathrm{B} 103=\left\{\begin{array}{l}
\text { Very bad effect, very little investment } 0 \sim 0.2 \\
\text { Bad effect, little investment } 0.2 \sim 0.4 \\
\text { General effect, general investment } 0.4 \sim 0.6 \\
\text { Good effect, high investment 0.6 0.8 } \\
\text { Very good effect, very high investment } 0.8 \sim 1
\end{array}\right.
$$

(4) Effectiveness of investigation of major pollution sources (B104)

$$
\mathrm{B} 104=\left\{\begin{array}{l}
\text { Very bad effect, very little investment } 0 \sim 0.2 \\
\text { Bad effect, little investment } 0.2 \sim 0.4 \\
\text { General effect, general investment 0.4 0.6 } \\
\text { Good effect, high investment 0.6 0.8 } \\
\text { Very good effect, very high investment } 0.8 \sim 1
\end{array}\right.
$$

(5) Timeliness of early warning information transmission (B105)

$$
\mathrm{B} 105=\left\{\begin{array}{l}
\text { Very bad effect, very untimely } 0 \sim 0.2 \\
\text { Bad effect, untimely } 0.2 \sim 0.4 \\
\text { General effect, timely } 0.4 \sim 0.6 \\
\text { Good effect, relatively timely } 0.6 \sim 0.8 \\
\text { Very good effect, very timely } 0.8 \sim 1
\end{array}\right.
$$

(6) Development level of monitoring technology (B106)

$$
\mathrm{B} 106=\left\{\begin{array}{l}
\text { Very bad effect, very low level } 0 \sim 0.2 \\
\text { Bad effect, low level 0.2 0.4 } \\
\text { General effect, general level 0.4 0.6 } \\
\text { Good effect, high level 0.6 0.8 } \\
\text { Very good effect, very high level 0.8 1 }
\end{array}\right.
$$

(7) Accuracy of equipment monitoring results (B107)

$$
\mathrm{B} 107=\left\{\begin{array}{l}
\text { Very bad effect, very inaccurate } 0 \sim 0.2 \\
\text { Bad effect, inaccurate } 0.2 \sim 0.4 \\
\text { General effect, accurate } 0.4 \sim 0.6 \\
\text { Good effect, relatively accurate } 0.6 \sim 0.8 \\
\text { Very good effect, very accurate } 0.8 \sim 1
\end{array}\right.
$$

(8) Quantity of risk monitoring equipment (B108)

$$
\mathrm{B} 108=\left\{\begin{array}{l}
\text { Very bad effect, very poor equipped } 0 \sim 0.2 \\
\text { Bad effect, poor equipped } 0.2 \sim 0.4 \\
\text { General effect, general equipped } 0.4 \sim 0.6 \\
\text { good effect, well equipped 0.6 0.8 } \\
\text { Very good effect, very well equipped } 0.8 \sim 1
\end{array}\right.
$$


(9) Proportion of professional monitors (B109)

$$
\mathrm{B} 109=\left\{\begin{array}{l}
\text { Very low proportion } 0 \sim 0.2 \\
\text { Low proportion } 0.2 \sim 0.4 \\
\text { General proportion } 0.4 \sim 0.6 \\
\text { High proportion } 0.6 \sim 0.8 \\
\text { Very high proportion } 0.8 \sim 1
\end{array}\right.
$$

(10) Effectiveness of incident reporting process (B110)

$$
\mathrm{B} 110=\left\{\begin{array}{l}
\text { Very bad effect, very unsound } 0 \sim 0.2 \\
\text { Bad effect, unsound } 0.2 \sim 0.4 \\
\text { General effect, general sound } 0.4 \sim 0.6 \\
\text { Good effect, relatively sound } 0.6 \sim 0.8 \\
\text { Very good effect, very sound } 0.8 \sim 1
\end{array}\right.
$$

(11) Perfection of emergency rules and regulations (B111)

$$
\mathrm{B} 111=\left\{\begin{array}{l}
\text { Very bad } 0 \sim 0.2 \\
\text { bad } 0.2 \sim 0.4 \\
\text { good } 0.4 \sim 0.6 \\
\text { relatively good } 0.6 \sim 0.8 \\
\text { very good } 0.8 \sim 1
\end{array}\right.
$$

(12) Broadcast media level before the accident (B112)

$$
\mathrm{B} 112=\left\{\begin{array}{l}
\text { Very bad effect, very low level } 0 \sim 0.2 \\
\text { bad effect, low level 0.2 0.4 } \\
\text { General effect, general level 0.4 0.6 } \\
\text { Good effect, high level 0.6 0.8 } \\
\text { Very good effect, very high level } 0.8 \sim 1
\end{array}\right.
$$

(13) Soundness of emergency management organization (B113)

$$
\mathrm{B} 113=\left\{\begin{array}{l}
\text { Very bad effect, very unsound } 0 \sim 0.2 \\
\text { Bad effect, unsound } 0.2 \sim 0.4 \\
\text { General effect, general sound } 0.4 \sim 0.6 \\
\text { Good effect, relatively sound } 0.6 \sim 0.8 \\
\text { Very good effect, very sound } 0.8 \sim 1
\end{array}\right.
$$

(14) Validity of alarm program (B114)

$$
\mathrm{B} 114=\left\{\begin{array}{l}
\text { Very little investment, very bad effect } 0 \sim 0.2 \\
\text { little investment, bad effect } 0.2 \sim 0.4 \\
\text { General investment, general effect } 0.4 \sim 0.6 \\
\text { High investment, good effect } 0.6 \sim 0.8 \\
\text { Very high investment, very good effect } 0.8 \sim 1
\end{array}\right.
$$

(15) Propaganda and presentation skills to public (B201)

$$
\mathrm{B} 201=\left\{\begin{array}{l}
\text { Very bad effect } 0 \sim 0.2 \\
\text { Bad effect } 0.2 \sim 0.4 \\
\text { General effect } 0.4 \sim 0.6 \\
\text { Good effect } 0.6 \sim 0.8 \\
\text { Very good effect } 0.8 \sim 1
\end{array}\right.
$$


(16) Emergency preparedness drill level (B202)

$$
\mathrm{B} 202=\left\{\begin{array}{l}
\text { No } 0 \\
\text { At least once a year } 1
\end{array}\right.
$$

(17) Effectiveness of hazard source monitoring (B203)

$$
\text { B203 }=\left\{\begin{array}{l}
\text { Very bad effect, very little investment } 0 \sim 0.2 \\
\text { Bad effect, little investment } 0.2 \sim 0.4 \\
\text { General effect, general investment } 0.4 \sim 0.6 \\
\text { Good effect, high investment } 0.6 \sim 0.8 \\
\text { Very good effect, very high investment } 0.8 \sim 1
\end{array}\right.
$$

(18) Frequency of emergency training (B204)

$$
\text { B204 }=\left\{\begin{array}{l}
\text { Very low investment, very low frequency } 0 \sim 0.2 \\
\text { Low investment, low frequency 0.2 0.4 } \\
\text { General investment, general frequency 0.4 0.6 } \\
\text { high investment, high frequency 0.6 0.8 } \\
\text { Very high investment, very high frequency } 0.8 \sim 1
\end{array}\right.
$$

(19) Self-help knowledge education level (B205)

$$
\text { B205 }=\left\{\begin{array}{l}
\text { Very low level } 0 \sim 0.2 \\
\text { Low level 0.2 0.4 } \\
\text { General level 0.4 0.6 } \\
\text { High level 0.6 0.8 } \\
\text { Very high level 0.8 1 }
\end{array}\right.
$$

(20) Number of emergency professionals (B206)

$$
\text { B206 }=\left\{\begin{array}{l}
\text { Very little investment, very small number } 0.2 \\
\text { Little investment, small number } 0.4 \\
\text { General investment, general number } 0.6 \\
\text { High investment, large number } 0.8 \\
\text { Very high investment, very large number } 1
\end{array}\right.
$$

(21) Shelter area (B207)

$$
\text { B207 }=\left\{\begin{array}{l}
\text { Very little area } 0 \sim 0.2 \\
\text { Little area } 0.2 \sim 0.4 \\
\text { General area } 0.4 \sim 0.6 \\
\text { Large area } 0.6 \sim 0.8 \\
\text { Very large area } 0.8 \sim 1
\end{array}\right.
$$

(22) Amount of government emergency funds (B208)

$$
\text { B208 }=\left\{\begin{array}{l}
\text { Very little investment } 0 \sim 0.2 \\
\text { Little investment } 0.2 \sim 0.4 \\
\text { General investment } 0.4 \sim 0.6 \\
\text { High investmen } 0.6 \sim 0.8 \\
\text { Very high investment } 0.8 \sim 1
\end{array}\right.
$$


(23) Reserve guarantee of emergency resources (B209)

$$
\mathrm{B} 209=\left\{\begin{array}{l}
\text { Very little investment, very bad guarantee } 0 \sim 0.2 \\
\text { Little investment, bad guarantee } 0.2 \sim 0.4 \\
\text { General investment, general guaranteev } 0.4 \sim 0.6 \\
\text { High investmen, good guarantee } 0.6 \sim 0.8 \\
\text { Very high investment, very good guarantee } 0.8 \sim 1
\end{array}\right.
$$

(24) Number of environmental supervisors (B210)

$$
\mathrm{B} 210=\left\{\begin{array}{l}
\text { Very small number } 0 \sim 0.2 \\
\text { Small number } 0.2 \sim 0.4 \\
\text { General number } 0.4 \sim 0.6 \\
\text { Large number } 0.6 \sim 0.8 \\
\text { Very large number } 0.8 \sim 1
\end{array}\right.
$$

(25) Environmental protection knowledge level of supervisor (B211)

$$
\mathrm{B} 211=\left\{\begin{array}{l}
\text { Very low level } 0 \sim 0.2 \\
\text { Low level } 0.2 \sim 0.4 \\
\text { General level } 0.4 \sim 0.6 \\
\text { High level 0.6 0.8 } \\
\text { Very high level } 0.8 \sim 1
\end{array}\right.
$$

(26) Traffic control level (B212)

$$
\mathrm{B} 212=\left\{\begin{array}{l}
\text { Very little investment, very low level } 0 \sim 0.2 \\
\text { little investment, low level } 0.2 \sim 0.4 \\
\text { General investment, general level } 0.4 \sim 0.6 \\
\text { High investment, high level 0.6 0.8 } \\
\text { Very high investment, very high level } 0.8 \sim 1
\end{array}\right.
$$

(27) Coverage of emergency management agencies (B213)

$$
\mathrm{B} 213=\left\{\begin{array}{l}
\text { Very little investment, very low coverage rate } 0 \sim 0.2 \\
\text { little investment, low coverage rate } 0.2 \sim 0.4 \\
\text { General investment, general coverage rate } 0.4 \sim 0.6 \\
\text { High investment, high coverage rate } 0.6 \sim 0.8 \\
\text { Very high investment, very high coverage rate } 0.8 \sim 1
\end{array}\right.
$$

(28) Coverage of emergency plans (B214)

$$
\mathrm{B} 214=\left\{\begin{array}{l}
\text { Very little investment, very low coverage rate } 0 \sim 0.2 \\
\text { little investment, low coverage rate } 0.2 \sim 0.4 \\
\text { General investment, general coverage rate } 0.4 \sim 0.6 \\
\text { High investment, high coverage rate } 0.6 \sim 0.8 \\
\text { Very high investment, very high coverage rate } 0.8 \sim 1
\end{array}\right.
$$

(29) Regional population density (B215)

$$
\mathrm{B} 215=\left\{\begin{array}{l}
\text { Very low density } 0 \sim 0.2 \\
\text { Low density } 0.2 \sim 0.4 \\
\text { General density } 0.4 \sim 0.6 \\
\text { High density } 0.6 \sim 0.8 \\
\text { Very high density } 0.8 \sim 1
\end{array}\right.
$$


(30) Evacuation speed of organized rescue (B301)

$$
\mathrm{B} 301=\left\{\begin{array}{l}
\text { Very slow speed } 0 \sim 0.2 \\
\text { Low speed 0.2 0.4 } \\
\text { General speed } 0.4 \sim 0.6 \\
\text { High speed 0.6 0.8 } \\
\text { Very high speed } 0.8 \sim 1
\end{array}\right.
$$

(31) Accuracy of accident development trend judgment (B302)

$$
\text { B302 }=\left\{\begin{array}{l}
\text { Very low accuracy } 0 \sim 0.2 \\
\text { Low accuracy } 0.2 \sim 0.4 \\
\text { General accuracy } 0.4 \sim 0.6 \\
\text { High accuracy } 0.6 \sim 0.8 \\
\text { Very high accuracy } 0.8 \sim 1
\end{array}\right.
$$

(32) Pertinence of emergency rescue work (B303)

$$
\mathrm{B} 303=\left\{\begin{array}{l}
\text { Very bad effect, very low pertinence } 0 \sim 0.2 \\
\text { Bad effect, low pertinence } 0.2 \sim 0.4 \\
\text { General effect, general pertinence } 0.4 \sim 0.6 \\
\text { Good effect, high pertinence } 0.6 \sim 0.8 \\
\text { Very good effect, very high pertinence } 0.8 \sim 1
\end{array}\right.
$$

(33) Effectiveness of secondary disaster monitoring information (B304)

$$
\text { B304 }=\left\{\begin{array}{l}
\text { Very bad effect, very low validity } 0 \sim 0.2 \\
\text { Bad effect, low validity } 0.2 \sim 0.4 \\
\text { General effect, general validity } 0.4 \sim 0.6 \\
\text { Good effect, high validity } 0.6 \sim 0.8 \\
\text { Very good effect, very high validity } 0.8 \sim 1
\end{array}\right.
$$

(34) Effectiveness of dynamic monitoring of pollution range (B305)

$$
\text { B305 }=\left\{\begin{array}{l}
\text { Very bad effect, very low validity } 0 \sim 0.2 \\
\text { Bad effect, low validity } 0.2 \sim 0.4 \\
\text { General effect, general validity } 0.4 \sim 0.6 \\
\text { Good effect, high validity } 0.6 \sim 0.8 \\
\text { Very good effect, very high validity } 0.8 \sim 1
\end{array}\right.
$$

(35) Validity of situation assessment (B306)

$$
\text { B306 }=\left\{\begin{array}{l}
\text { Very bad effect, very low validity } 0 \sim 0.2 \\
\text { Bad effect, low validity } 0.2 \sim 0.4 \\
\text { General effect, general validity } 0.4 \sim 0.6 \\
\text { Good effect, high validity } 0.6 \sim 0.8 \\
\text { Very good effect, very high validity } 0.8 \sim 1
\end{array}\right.
$$

(36) Coordination degree between command and other departments (B307)

$$
\mathrm{B} 307=\left\{\begin{array}{l}
\text { Very bad effect, very low coordination degree } 0 \sim 0.2 \\
\text { Bad effect, low coordination degree } 0.2 \sim 0.4 \\
\text { General effect, general coordination degree } 0.4 \sim 0.6 \\
\text { Good effect, high coordination degree } 0.6 \sim 0.8 \\
\text { Very good effect, very high coordination degree } 0.8 \sim 1
\end{array}\right.
$$


(37) Investment level of rescue equipment (B308)

$$
\mathrm{B} 308=\left\{\begin{array}{l}
\text { Very little investment, very low level } 0 \sim 0.2 \mathrm{~B} \\
\text { little investment, low level } 0.2 \sim 0.4 \\
\text { General investment, general level } 0.4 \sim 0.6 \\
\text { High investment, high level 0.6 0.8 } \\
\text { Very high investment, very high level } 0.8 \sim 1
\end{array}\right.
$$

(38) Medical security capability (B309)

$$
\mathrm{B} 309=\left\{\begin{array}{l}
\text { Very little investment, very bad guarantee } 0 \sim 0.2 \\
\text { Little investment, bad guarantee } 0.2 \sim 0.4 \\
\text { General investment, general guarantee } v 0.4 \sim 0.6 \\
\text { High investmen, good guarantee } 0.6 \sim 0.8 \\
\text { Very high investment, very good guarantee } 0.8 \sim 1
\end{array}\right.
$$

(39) Proportion of emergency professionals (B310)

$$
\mathrm{B} 310=\left\{\begin{array}{l}
\text { Very low proportion } 0 \sim 0.2 \\
\text { Low proportion } 0.2 \sim 0.4 \\
\text { General proportion } 0.4 \sim 0.6 \\
\text { High proportion } 0.6 \sim 0.8 \\
\text { Very high proportion } 0.8 \sim 1
\end{array}\right.
$$

(40) Speed of replenishment of relief supplies (B311)

$$
\mathrm{B} 311=\left\{\begin{array}{l}
\text { Very bad effect, very low speed } 0 \sim 0.2 \\
\text { Bad effect, low speed } 0.2 \sim 0.4 \\
\text { General effect, general speed } 0.4 \sim 0.6 \\
\text { Good effect, high speed 0.6 0.8 } \\
\text { Very good effect, very high speed } 0.8 \sim 1
\end{array}\right.
$$

(41) Speed of relief materials allocation (B312)

$$
\mathrm{B} 312=\left\{\begin{array}{l}
\text { Very bad effect, very low speed } 0 \sim 0.2 \\
\text { Bad effect, low speed } 0.2 \sim 0.4 \\
\text { General effect, general speed } 0.4 \sim 0.6 \\
\text { Good effect, high speed 0.6 0.8 } \\
\text { Very good effect, very high speed } 0.8 \sim 1
\end{array}\right.
$$

(42) Comprehensiveness of the accident case database (B313)

$$
\mathrm{B} 313=\left\{\begin{array}{l}
\text { Very little investment, very incomprehensive } 0 \sim 0.2 \\
\text { little investment, incomprehensive } 0.2 \sim 0.4 \\
\text { General investment, general comprehensive } 0.4 \sim 0.6 \\
\text { High investment, relatively comprehensive } 0.6 \sim 0.8 \\
\text { Very high investment, very comprehensive } 0.8 \sim 1
\end{array}\right.
$$

(43) Number of decision command personnel (B314)

$$
\mathrm{B} 314=\left\{\begin{array}{l}
\text { Very small number } 0 \sim 0.2 \\
\text { Small number } 0.2 \sim 0.4 \\
\text { General number } 0.4 \sim 0.6 \\
\text { Large number } 0.6 \sim 0.8 \\
\text { Very large number } 0.8 \sim 1
\end{array}\right.
$$


(44) Effectiveness of the expert support system (B315)

$$
\mathrm{B} 315=\left\{\begin{array}{l}
\text { Very bad effect, very low validity } 0 \sim 0.2 \\
\text { Bad effect, low validity } 0.2 \sim 0.4 \\
\text { General effect, general validity } 0.4 \sim 0.6 \\
\text { Good effect, high validity } 0.6 \sim 0.8 \\
\text { Very good effect, very high validity } 0.8 \sim 1
\end{array}\right.
$$

(45) Coverage rate of emergency command technical system (B316)

$$
\mathrm{B} 316=\left\{\begin{array}{l}
\text { Very little investment, very low coverage rate } 0 \sim 0.2 \\
\text { little investment, low coverage rate } 0.2 \sim 0.4 \\
\text { General investment, general coverage rate } 0.4 \sim 0.6 \\
\text { High investment, high coverage rate } 0.6 \sim 0.8 \\
\text { Very high investment, very high coverage rate } 0.8 \sim 1
\end{array}\right.
$$

(46) Health care capacity ( B317)

$$
\mathrm{B} 317=\left\{\begin{array}{l}
\text { Very little investment, very bad guarantee } 0 \sim 0.2 \\
\text { Little investment, bad guarantee } 0.2 \sim 0.4 \\
\text { General investment, general guaranteev } 0.4 \sim 0.6 \\
\text { High investmen, good guarantee } 0.6 \sim 0.8 \\
\text { Very high investment, very good guarantee } 0.8 \sim 1
\end{array}\right.
$$

(47) Reporting speed of accident rescue progress (B318)

$$
\mathrm{B} 318=\left\{\begin{array}{l}
\text { Very bad effect, very low speed } 0 \sim 0.2 \\
\text { Bad effect, low speed } 0.2 \sim 0.4 \\
\text { General effect, general speed } 0.4 \sim 0.6 \\
\text { Good effect, high speed } 0.6 \sim 0.8 \\
\text { Very good effect, very high speed } 0.8 \sim 1
\end{array}\right.
$$

(48) Broadcast media level in the accident (B319)

$$
\mathrm{B} 319=\left\{\begin{array}{l}
\text { Very little investment, very low level } 0 \sim 0.2 \mathrm{~B} \\
\text { little investment, low level } 0.2 \sim 0.4 \\
\text { General investment, general level } 0.4 \sim 0.6 \\
\text { High investment, high level 0.6 0.8 } \\
\text { Very high investment, very high level } 0.8 \sim 1
\end{array}\right.
$$

(49) Unobstructed degree of the emergency resource inquiry system (B320)

$$
\mathrm{B} 320=\left\{\begin{array}{l}
\text { Very little investment, very low unobstructed degree } 0 \sim 0.2 \mathrm{~B} \\
\text { little investment, low unobstructed degree } 0.2 \sim 0.4 \\
\text { General investment, general unobstructed degree } 0.4 \sim 0.6 \\
\text { High investment, high unobstructed degree } 0.6 \sim 0.8 \\
\text { Very high investment, very high unobstructed degree } 0.8 \sim 1
\end{array}\right.
$$

(50) Coverage rate of emergency command sites (B321)

$$
\mathrm{B} 321=\left\{\begin{array}{l}
\text { Very little investment, very low coverage rate } 0 \sim 0.2 \\
\text { little investment, low coverage rate } 0.2 \sim 0.4 \\
\text { General investment, general coverage rate } 0.4 \sim 0.6 \\
\text { High investment, high coverage rate } 0.6 \sim 0.8 \\
\text { Very high investment, very high coverage rate } 0.8 \sim 1
\end{array}\right.
$$


(51) Soundness of established emergency response system (B322)

$$
\text { B322 }=\left\{\begin{array}{l}
\text { Very little investment, very unsound } 0 \sim 0.2 \\
\text { little investment, unsound 0.2 0.4 } \\
\text { General investment, general sound } 0.4 \sim 0.6 \\
\text { High investment, relatively sound } 0.6 \sim 0.8 \\
\text { Very high investment, very sound } 0.8 \sim 1
\end{array}\right.
$$

(52) Implementation degree of emergency plan (B323)

$$
\text { B323 }=\left\{\begin{array}{l}
\text { Very bad effect, very low implementation degree } 0 \sim 0.2 \\
\text { Bad effect, low implementation degree 0.2 0.4 } \\
\text { General effect, general implementation degree 0.4 0.6 } \\
\text { Good effect, high implementation degree 0.6 0.8 } \\
\text { Very good effect, very high implementation degree 0.8 1 }
\end{array}\right.
$$

(53) Validity of accident development trend analysis (B401)

$$
\mathrm{B} 401=\left\{\begin{array}{l}
\text { Very bad effect, very low validity } 0 \sim 0.2 \\
\text { Bad effect, low validity } 0.2 \sim 0.4 \\
\text { General effect, general validity } 0.4 \sim 0.6 \\
\text { Good effect, high validity 0.6 0.8 } \\
\text { Very good effect, very high validity } 0.8 \sim 1
\end{array}\right.
$$

(54) Casualty statistics capability (B402)

$$
\mathrm{B} 402=\left\{\begin{array}{l}
\text { Very bad effect } 0 \sim 0.2 \\
\text { Bad effect } 0.2 \sim 0.4 \\
\text { General effect } 0.4 \sim 0.6 \\
\text { Good effect } 0.6 \sim 0.8 \\
\text { Very good effect } 0.8 \sim 1
\end{array}\right.
$$

(55) Accident mechanism summary ability (B403)

$$
\mathrm{B} 403=\left\{\begin{array}{l}
\text { Very low ability } 0 \sim 0.2 \\
\text { Low ability } 0.2 \sim 0.4 \\
\text { General ability } 0.4 \sim 0.6 \\
\text { High ability } 0.6 \sim 0.8 \\
\text { Very high ability } 0.8 \sim 1
\end{array}\right.
$$

(56) Investigate and assess capacity of accident losses (B404)

$$
\text { B404 }=\left\{\begin{array}{l}
\text { Very bad effect } 0 \sim 0.2 \\
\text { Bad effect } 0.2 \sim 0.4 \\
\text { General effect } 0.4 \sim 0.6 \\
\text { Good effect } 0.6 \sim 0.8 \\
\text { Very good effect } 0.8 \sim 1
\end{array}\right.
$$

(57) Responsibility degree for the accident (B405)

$$
\mathrm{B} 405=\left\{\begin{array}{l}
\text { Very little investment, very low implementation degree } 0 \sim 0.2 \mathrm{~B} \\
\text { little investment, low implementation degree } 0.2 \sim 0.4 \\
\text { General investment, general implementationdegree } 0.4 \sim 0.6 \\
\text { High investment, high implementation degree 0.6 0.8 } \\
\text { Very high investment, very high implementation degree } 0.8 \sim 1
\end{array}\right.
$$


(58) Emergency resource integration capability (B406)

$$
\mathrm{B} 406=\left\{\begin{array}{l}
\text { Very low ability } 0 \sim 0.2 \\
\text { Low ability } 0.2 \sim 0.4 \\
\text { General ability } 0.4 \sim 0.6 \\
\text { High ability } 0.6 \sim 0.8 \\
\text { Very high ability } 0.8 \sim 1
\end{array}\right.
$$

(59) Emergency management and control level (B407)

$$
\mathrm{B} 407=\left\{\begin{array}{l}
\text { Very low level } 0 \sim 0.2 \\
\text { Low level } 0.2 \sim 0.4 \\
\text { General level 0.4 0.6 } \\
\text { High level 0.6 0.8 } \\
\text { Very high level } 0.8 \sim 1
\end{array}\right.
$$

(60) Emergency funds reserve level (B408)

$$
\mathrm{B} 408=\left\{\begin{array}{l}
\text { Very low level } 0 \sim 0.2 \\
\text { Low level } 0.2 \sim 0.4 \\
\text { General level } 0.4 \sim 0.6 \\
\text { High level 0.6 0.8 } \\
\text { Very high level } 0.8 \sim 1
\end{array}\right.
$$

(61) Effectiveness of social insurance and assistance (B409)

$$
\mathrm{B} 409=\left\{\begin{array}{l}
\text { Very bad effect, very low validity } 0 \sim 0.2 \\
\text { Bad effect, low validity } 0.2 \sim 0.4 \\
\text { General effect, general validity } 0.4 \sim 0.6 \\
\text { Good effect, high validity } 0.6 \sim 0.8 \\
\text { Very good effect, very high validity } 0.8 \sim 1
\end{array}\right.
$$

(62) Compliance of fund use audit system (B410)

$$
\mathrm{B} 410=\left\{\begin{array}{l}
\text { Very bad effect, very unreasonable } 0.2 \\
\text { Bad effect, unreasonable } 0.4 \\
\text { General effect, general reasonable } 0.6 \\
\text { Good effect, reasonable } 0.8 \\
\text { Very good effect, very reasonable } 1
\end{array}\right.
$$

(63) Validity of the establishment of psychological counseling and relief stations (B411)

$$
\mathrm{B} 411=\left\{\begin{array}{l}
\text { Very bad effect, very low validity } 0 \sim 0.2 \\
\text { Bad effect, low validity } 0.2 \sim 0.4 \\
\text { General effect, general validity } 0.4 \sim 0.6 \\
\text { Good effect, high validity } 0.6 \sim 0.8 \\
\text { Very good effect, very high validity } 0.8 \sim 1
\end{array}\right.
$$

(64) Long-term effect of government investment system (B412)

$$
\mathrm{B} 412=\left\{\begin{array}{l}
\text { Very low investment, very low validity } 0 \sim 0.2 \\
\text { Low investment, low validity } 0.2 \sim 0.4 \\
\text { General investment, general validity } 0.4 \sim 0.6 \\
\text { High investment, high validity } 0.6 \sim 0.8 \\
\text { Very high investment, very high validity } 0.8 \sim 1
\end{array}\right.
$$


(65) Relationship maintaining with government and non-governmental organizations (B413)

$$
\mathrm{B} 413=\left\{\begin{array}{l}
\text { Very bad effect } 0 \sim 0.2 \\
\text { Bad effect } 0.2 \sim 0.4 \\
\text { General effect } 0.4 \sim 0.6 \\
\text { Good effect } 0.6 \sim 0.8 \\
\text { Very good effect } 0.8 \sim 1
\end{array}\right.
$$

(66) Perfection level of information feedback system (B414)

$$
\mathrm{B} 414=\left\{\begin{array}{l}
\text { Very little investment, very low perfection level 0 0.2 } \\
\text { little investment, low perfection level 0.2 0.4 } \\
\text { General investment, general high perfection level 0.4 0.6 } \\
\text { High investment, relatively high perfection level 0.6 0.8 } \\
\text { Very high investment, very high perfection level 0.8 1 }
\end{array}\right.
$$

(67) Implementation degree of supervision and prevention right of the supervision department (B415)

$$
\mathrm{B} 415=\left\{\begin{array}{l}
\text { Very bad effect, very low implementation degree } 0 \sim 0.2 \\
\text { Bad effect, low implementation degree 0.2 0.4 } \\
\text { General effect, general implementation degree 0.4 0.6 } \\
\text { Good effect, high implementation degree 0.6 0.8 } \\
\text { Very good effect, very high implementation degree } 0.8 \sim 1
\end{array}\right.
$$

(68) Recovery degree of water, electricity and gas (B416)

$$
\mathrm{B} 416=\left\{\begin{array}{l}
\text { Very little investment, very low recovery degree } 0 \sim 0.2 \mathrm{~B} \\
\text { little investment, low recovery degree } 0.2 \sim 0.4 \\
\text { General investment, general recovery degree } 0.4 \sim 0.6 \\
\text { High investment, high recovery degree } 0.6 \sim 0.8 \\
\text { Very high investment, very high recovery degree } 0.8 \sim 1
\end{array}\right.
$$

\section{References}

1. NBS. Statistical Communique of the People's Republic of China on the 2020 National Economic and Social Development; National Bureau of Statistics of China: Beijing, China, 2021.

2. Editorial Board of China Urban Development Report. China City Development Report of 2019 and 2020. 2020. Available online: http://www.citieschina.org/news/c_2618/gNALBI_1.html (accessed on 7 December 2020). (In Chinese).

3. Hao, Y.; Zheng, S.; Zhao, M.; Wu, H.; Guo, Y.; Li, Y. Reexamining the relationships among urbanization, industrial structure, and environmental pollution in China-New evidence using the dynamic threshold panel model. Energy Rep. 2020, 6, 28-39. [CrossRef]

4. Liang, L.; Wang, Z.; Li, J. The effect of urbanization on environmental pollution in rapidly developing urban agglomerations. J. Clean Prod. 2019, 23, 117649. [CrossRef]

5. Liang, W.; Yang, M. Urbanization, economic growth and environmental pollution: Evidence from China. Sustain. Comput. Inform. Syst. 2019, 21, 1-9. [CrossRef]

6. Liu, X.; Xu, Y.; Ge, Y.; Zhang, W.; Herrera, F. A group decision making approach considering self-confidence behaviors and its application in environmental pollution emergency management. Int. J. Environ. Res. Public Health 2019, 16, 385. [CrossRef] [PubMed]

7. Shi, S.; Cao, J.; Feng, L.; Liang, W.; Zhang, L. Construction of a technique plan repository and evaluation system based on AHP group decision-making for emergency treatment and disposal in chemical pollution accidents. J. Hazard. Mater. 2014, 276, 200-206. [CrossRef] [PubMed]

8. Wang, D.; Wan, K.; Ma, W. Emergency decision-making model of environmental emergencies based on case-based reasoning method. J. Environ. Manag. 2020, 262, 110382. [CrossRef] [PubMed]

9. Wang, D.; Sun, J. Modelling and simulation of enterprise emergency evolution dynamics based on behavior perspective. J. Intell. 2015, 34, 97-103. (In Chinese) 
10. Chen, N.; Zhou, D.; Ma, Y.; Chen, A. Evolution prediction of unconventional emergencies via neural network: An empirical study of megacities. Int. J. Disaster Risk Reduct. 2019, 39, 101243. [CrossRef]

11. Niu, M.; Zhu, S.; Du, C.; Yang, N.; Xu, W. Study and application of typical disaster monitoring and early warning system in metal mine. Procedia Eng. 2012, 45, 125-130. [CrossRef]

12. Kitazawa, K.; Hale, S.A. Social media and early warning systems for natural disasters: A case study of Typhoon Etau in Japan. Int. J. Disaster Risk Reduct. 2021, 52, 101926. [CrossRef]

13. Avnet, T.; Laufer, D. Exploring the effectiveness of creating regulatory fit in crisis communications: Can it change perceptions of media coverage during a crisis? Bus. Horiz. 2014, 58, 149-156. [CrossRef]

14. Chen, A.; Chen, N.; Li, J. During-incident process assessment in emergency management: Concept and strategy. Saf. Sci. 2012, 50, 90-102. [CrossRef]

15. Liu, D.; Li, Y.; Fang, S.; Zhang, Y. Influencing factors for emergency evacuation capability of rural households to flood hazards in western mountainous regions of Henan province, China. Int. J. Disaster Risk Reduct. 2017, 21, 187-195. [CrossRef]

16. Deng, Y.; Su, G.; Gao, N.; Sun, L. Investigation and analysis of the importance awareness of the factors affecting the earthquake emergency and rescue in different areas: A case study of Yunnan and Jiangsu Provinces. Int. J. Disaster Risk Reduct. 2017, 25, 163-172. [CrossRef]

17. Kontokosta, C.E.; Malik, A. The resilience to emergencies and disasters index: Applying big data to benchmark and validate neighborhood resilience capacity. Sustain. Cities Soc. 2018, 36, 272-285. [CrossRef]

18. Qi, K.; Wang, Q.; Duan, Q.; Gong, L.; Sun, J.; Liew, K.M.; Jiang, L. A multi criteria comprehensive evaluation approach for emergency response capacity with interval 2-tuple linguistic information. Appl. Soft. Comput. 2018, 72, 419-441. [CrossRef]

19. Zhou, J.; Reniers, G. Petri net simulation of multi-department emergency response to avert domino effects in chemical industry accidents. Process Saf. Environ. Protect. 2021, 146, 916-926. [CrossRef]

20. Fan, B.; Liu, R.; Huang, K.; Zhu, Y. Embeddedness in cross-agency collaboration and emergency management capability: Evidence from Shanghai's urban contingency plans. Gov. Inf. Q. 2019, 36, 101395. [CrossRef]

21. Nesticò, A.; Fiore, P.; D'Andria, E. Enhancement of small towns in inland areas: A novel indicators dataset to evaluate sustainable plans. Sustainability 2020, 12, 6359. [CrossRef]

22. Du, Y.; Sun, J.; Duan, Q.; Qi, K.; Xiao, H.; Liew, K.M. Optimal assignments of allocating and scheduling emergency resources to accidents in chemical industrial parks. J. Loss Prev. Process Ind. 2020, 65, 104148. [CrossRef]

23. Hoscan, O.; Cetinyokus, S. Determination of emergency assembly point for industrial accidents with AHP analysis. J. Loss Prev. Process. Ind. 2021, 69, 104386. [CrossRef]

24. Yu, A.; Jia, Z.; Zhang, W.; Deng, K.; Herrera, F. A dynamic credit index system for TSMEs in China using the Delphi and analytic Hierarchy process (AHP) methods. Sustainability 2020, 12, 1715. [CrossRef]

25. Jin, W.; An, W.; Zhao, Y.; Qiu, Z.; Li, J.; Song, S. Research on evaluation of emergency response capacity of oil spill emergency vessels. Aquat. Procedia 2015, 3, 66-73.

26. Liu, Y. An improved AHP and BP neural network method for service quality evaluation of city bus. Int. J. Comput. Appl. Technol. 2018, 58, 37-44. [CrossRef]

27. Ju, Y.; Wang, A. Emergency alternative evaluation under group decision makers: A method of incorporating DS/AHP with extended TOPSIS. Expert Syst. Appl. 2012, 39, 1315-1323. [CrossRef]

28. Ju, Y.; Wang, A.; Liu, X. Evaluating emergency response capacity by fuzzy AHP and 2-tuple fuzzy linguistic approach. Expert Syst. Appl. 2012, 39, 6972-6981. [CrossRef]

29. Alexander, D.E. Principles of Emergency Planning and Management; Oxford University Press on Demand: New York, NY, USA, 2002.

30. Wang, H. The main task of China's urbanization at the present stage and its great significance. Econ. Perspect. 2012, 9, 49-56. (In Chinese)

31. Yang, D.; Kao, W.T.M.; Huang, N.; Wang, R.; Zhang, X.; Zhou, W. Process-based environmental communication and conflict mitigation during sudden pollution accidents. J. Clean Prod. 2014, 66, 1-9. [CrossRef]

32. Yang, Y.; Lei, X.; Long, Y.; Tian, Y.; Zhang, Y.; Yao, Y.; Hou, X.; Shi, M.; Wang, P.; Zhang, C.; et al. A novel comprehensive risk assessment method for sudden water accidents in the Middle Route of the South-North Water Transfer Project (China). Sci. Total Environ. 2020, 698, 134167. [CrossRef]

33. Hou, J.; Gai, W.M.; Cheng, W.Y.; Deng, Y.F. Hazardous chemical leakage accidents and emergency evacuation response from 2009 to 2018 in China: A review. Saf. Sci. 2021, 135, 105101. [CrossRef]

34. Zhang, J.; Huang, W.; Xu, J. Evaluation of the city emergency capacity based on the evidence theory. Math. Probl. Eng. 2013, 2013, 1-6. [CrossRef]

35. Liu, Y.; Xu, W.; Qiao, H.; Fan, W. Research progress of emergency management methods. Manag. Rev. 2016, 28, 3. (In Chinese)

36. Son, C.; Sasangohar, F.; Neville, T.; Peres, S.C.; Moon, J. Investigating resilience in emergency management: An integrative review of literature. Appl. Ergon. 2020, 87, 103114. [CrossRef]

37. Ju, Y.; Wang, A.; You, T. Emergency alternative evaluation and selection based on ANP, DEMATEL, and TL-TOPSIS. Nat. Hazards 2015, 75, 347-379. [CrossRef]

38. Li, Y.; Hu, Y.; Zhang, X.; Deng, Y.; Mahadevan, S. An evidential DEMATEL method to identify critical success factors in emergency management. Appl. Soft. Comput. 2014, 22, 504-510. [CrossRef] 
39. Chen, L.; Li, Z.; Deng, X. Emergency alternative evaluation under group decision makers: A new method based on entropy weight and DEMATEL. Int. J. Syst. Sci. 2020, 51, 570-583. [CrossRef]

40. Zhang, G.; Ma, J.; Lu, J. Emergency management evaluation by a fuzzy multi-criteria group decision support system. Stoch. Environ. Res. Risk Assess. 2009, 23, 517-527. [CrossRef]

41. Hu, Y.; Li, Y. Study on evaluation of emergency response capabilities of petrochemical enterprises based on extension method. J. Saf. Sci. Technol. 2013, 9, 144-149.

42. Ordoobadi, S.M. Application of ANP methodology in evaluation of advanced technologies. J. Manuf. Technol. Manag. 2012, 23, 229-252. [CrossRef]

43. Khan, A.U.; Ali, Y. Analytical hierarchy process (AHP) and analytical network process methods and their applications: A twenty year review from 2000-2019. Int. J. Anal. Hierarchy Process 2020, 12, 369-459.

44. Huang, J.J.; Tzeng, G.H.; Ong, C.S. Multidimensional data in multidimensional scaling using the analytic network process. Pattern Recognit. Lett. 2005, 26, 755-767. [CrossRef]

45. Bahurmoz, A.M. A strategic model for safety during the Hajj pilgrimage: An ANP application. J. Syst. Sci. Syst. Eng. 2006, 15, 201-216. [CrossRef]

46. NBS. China City Statistical Yearbook 2020; China Statistics Press: Beijing, China, 2020. 